\title{
Sorgun Kazası XIX. YüzyıI Temettüat Defterleri Üzerinden Gelir Dağılımı ve Göreli Yoksulluk Üzerine Bir İnceleme
}

\author{
Ahmet Burçin YERELİ \\ aby@hacettepe.edu.tr
}

\author{
Altuğ Murat KÖKTAŞ \\ altugmuratkoktas@nigde.edu.tr
}

Iş11 Şirin SELÇUK

isselcuk@ankara.edu.tr

\section{A Study for Income Distribution and Relative Poverty on Temettuat Records of Sorgun Township in $19^{\text {th }}$ Century}

\begin{abstract}
Temettuat records which were implemented after Tanzimat reforms in the middle of the 19th century serves detailed information on the socio-economic characteristics of households. The present study aims to investigate the income distribution and relative poverty of Sorgun Township in Province of Sivas, Bozok Sanjak. In the study using data from 1844-1845 temettuat records income inequality is measured by using Lorenz Curve and Gini Coefficient and relative poverty rate is calculated by using fifty percent of the median income. The results show that, the pre-tax Gini coefficient is 0.3743 while Gini coefficient for after-tax income is 0.4031 . The relative poverty rate for before tax and after tax is $20 \%$ and $30 \%$, respectively. In this context, it is found that the tax system increased income inequality and the results were regressive.
\end{abstract}

Keywords

JEL Classification Codes $\quad$ : I31, I32, I38.
: Income Distribution, Relative Poverty, Lorenz Curve, Gini Coefficient, Ottoman State.

\section{Özet}

XIX. yüzyıl ortalarında Tanzimat Fermanı'yla birlikte uygulamaya konulan temettüat tahrirleri, hanehalkının sosyo-ekonomik özelliklerine ilișkin ayrıntılı bilgiler vermektedir. Çalıșmanın konusu, Sivas Eyaleti, Bozok Sancağına bağlı Sorgun Kazasında gelir dağılımı ve göreli yoksulluktur. 1844-1845 temettüat defterleri verilerinin kullanıldığı çalışmada gelir eşitsizliği Gini Katsayısı ve Lorenz Eğrisiyle incelenmiş, göreli yoksulluk oranı ise medyan gelirin yüzde ellisi kullanılarak hesaplanmıştır. Çalışmada Gini Katsayısı vergi öncesi 0,3743, vergi sonrası 0,4031 olarak bulunmuştur. Göreli yoksulluk oranı ise vergi öncesi \%20, vergi sonras $1 \% 31$ 'dir. Bu bağlamda vergi uygulamasının, gelir dağılımı eşitsizliğini artırdığ 1 ve regresif sonuçlar verdiği belirlenmiştir.

Anahtar Sözcükler

: Gelir Dağılımı, Göreli Yoksulluk, Lorenz Eğrisi, Gini Katsayısı, Osmanlı Devleti. 
Ahmet Burçin YERELİ \& Altuğ Murat KÖKTAŞ \& Işı1 Şirin SELÇUK

114 
Sorgun Kazası XIX. Yüzyıl Temettüat Defterleri Üzerinden Gelir Dağılımı ve Göreli Yoksulluk Üzerine Bir İnceleme

\section{Giriş}

Selçuklularda ortaya çıkarak, Türk İslam devletlerinde gelişen ve nihayet Osmanlı İmparatorluğu'na intikal eden tımar sistemi, devletin temel yap1 taş1 olarak değerlendirilmektedir. Fethedilen yerler, tımar ve zeamet olarak ayrılmakta, tımar sahibi söz konusu arazinin kendisine verilen kısmı üzerinden reayadan topladığı muayyen vergilerle geçinmekte, bunun karşıllığında ise teçhizatlı ve her an savaşa hazır asker yetiştirmektedir. Askerlikle tarımsal faaliyeti birleştiren bu sistem, savaşların uzun ve sonuçsuz olması nedeniyle üretici nüfusun olumsuz etkilenmesine neden olmuştur. Babadan oğula geçen tımar sisteminin XVI. yüzyılın ikinci yarısından itibaren bozulmaya başlamasıyla birlikte, devlet otoritesi zayıflayarak, mahalli beyler tarafindan ele geçirilmiştir. Bu durumun özellikle XVIII. yüzyılın ikinci yarısında ağalar, beyler ve ayanlar eliyle ortaya çıktığı görülmektedir. Saray halkı, beylerbeyleri, sancakbeyleri ve ocakağalarının tımarları kendi yakınları üzerine alarak ${ }^{1}$, hasılatı elde etmeleri sonucu tımarlı sipahi sayısı azalmış ve ulufeli asker sayısı artmıştır $^{2}$. Diğer yandan akçenin değer kaybetmesi ${ }^{3}$, maaşların reel olarak erimesine ve isyanlara neden olmuştur. Sonuç olarak askeri harcamalar ${ }^{4}$, hazine üzerindeki yük nedeniyle vergi artışlarını da beraberinde getirmiştir. Verginin iltizam usulüyle ${ }^{5}$ tahsil edilmesiyse imparatorluk çapında bir "mültezim” sınıfının oluşmasına ve reayanın aşırı düzeyde soyulmasına ${ }^{6}$ neden olmuştur (İnalcık, 2012: 35-9; İnalcık, 2013: 193; Cezar, 926).

I Bu durum Koçi Bey Risalesinde “... kan pahasına nice yüz yıl evvel fetholunmuş köyleri, tarlaları birer yolunu bulup, kimini paşmaklık ve arpalık, kimini mülk olarak verdirip, kendileri tamamen doyduktan sonra her biri adamlarına nice tımar ve zeametler verdirip, kılıç erbabının dirliklerini kestiler" ifadesiyle anlatılmaktadır (Danışman, 1985: 49).

2 1480'de 10.000 olan yeniçeri saylst, 1568'de 12.789, 1609'da 37.627, 1664'de 39.571 ve 1670'de 53.849'dur (İnalcık, 2013: 121-131; Barkan, 1960).

3 1584-85'te akçenin saf gümüş içeriği 0.61 gram iken 1592-93'te 0.34 gram ve 1597-98'de ise 0.23 gramdır. Benzer biçimde 1 Venedik dukası ise sirasıyla 68, 120 ve 230 akçedir (Pamuk, 2013: 88).

4 1524-5 yll bütçe giderleri 126.581 .347 akçe olup bunun 68.797 .803 akçesi askeri harcamalardan oluşmakta (\%54,3) ve bütçe 14.691 .311 akçe fazla vermektedir. 1567-68 yul bütçesine göre 221.532 .423 akçe olan giderlerin, 127.316 .983 akçesi askeri harcamalardan oluşmakta $\% 57,5)$ ve 4.670.635 akçe bütçe fazlast yer almaktadır. 1669-70 yll bütçesinde ise giderler 637.206.348 akçe iken, askeri harcamalar 285.905.688 akçe ve bütçe açı̆̆l 24.677 .388 akçedir. 1704-5 yılı bütçe rakamlarına göre 1.114.150.000 akçe olan giderlerin 372.100.000 akçesi askeri harcamalardan oluşurken, bütçe 167.500.000 akçe açık vermektedir (Genç ve Özvar, 2007). Rakamların karşılaştırllabilmesi için "Kise-i Divani”" rakamları, tarafimızca akçeye çevrilmiştir.

5 Abdülmecit Han (1823-1861), iltizam usulünü, “sirkat-1 müevvele (tevil edilmiş hırsızlık)” olarak tanımlamış (Aliye, 1995: 88) ve Tanzimat ile birlikte uygulamadan kaldırllmıştır. Ancak bir süre sonra yeniden uygulamaya konulmuştur.

6 Verginin yanında timar gelirine dâhil edilen tayyârât ve cerâ'im gibi çeşitli resimlerle küçük suçlar için alınan para cezaları, valilerin aldığ hazeriyye, seferiye, kudumiyye, teşrifiyye, mefruşat-bahâ, zahire-bahâ, âyâniyye, kapl-harcl, mübâşiriyye, kaftan-bahâ, menzil-beygiri, kolcu ve sair aidatlar ile avârz vergilerine bağll olarak ayan ve diğer görevlilerin hizmet ve masrafları karşılığında alınan aidatlar ve görevlilerin vergi toplamak için kendisinin, maiyetinin ve hayvanlarının yiyeceğini halkın üzerine yüklemesi ya da para istemesi, naiblerin görevleriyle ilgili olarak aldıkları resm-i kısmet, resm-i tereke, ilâm, hüccet, mürâsele, izinnâame, keşfiyye, 
I. Ahmed'in Adaletname'sinde “kadıların, nahiyelerini, kendilerine vekillik yapacak olanlara iltizama verdikleri, bir taraftan kadılarin ve diğer taraftan voyvodalarla uyumlu naiplerin beraberce halkı soyduklarl ve gezerlerken her kasaba ve köye yakin gelince mezarlıklarda yeni gömülmüss mezarları sayıp, bunlar ne zaman öldü? Metrukâtı ne oldu bize niçin haber vermediniz? Diye halka eziyet ettiklerini, cebren ölünün muhallefatın yazıp iki yüz akçe değer eşyayı bin ve bin beş yüz akçe bahaya tutup resm-i klsmet aldıklarını ve evvelce ölmüs olanların muhallefatını mükerreren yazıp resm-i kismet aldıklarl" vurgulanarak, söz konusu soygun örneklendirilmektedir (Uzunçarş11l, 2011: 121). Bununla birlikte imparatorluk içinde yeniçeri ocağı, ulema ve ayanların, devletin karar alma yetkilerini ele geçirme mücadelesinin siyasi bunalıma neden olması, mali sorunlar ile birleşerek, imparatorluğu uçurumun kenarına getirmiştir ${ }^{7}$. Bu nedenle toprak birliği ve idari bütünlüğün sağlanmasıyla birlikte merkezi devletin güçlenmesinin ancak mali yapının düzelmesiyle gerçekleşebileceği ileri sürülmektedir (Güran, 2011: 79). Bu durum, Kanuni Sultan Süleyman'ın veziriazamı olan Lütfü Paşa tarafından, ünlü eseri Âsafnâme'de “saltanat, hazine ile olur, zulüm ile olmaz" ifadesiyle özetlenebilir (1991: 34).

II. Mahmut'un (1808-1839) veziriazamı olan Alemdar Mustafa Paşa, imparatorluk içinde birliği yeniden tesis ederek, merkezi devlet otoritesini sağlamak ve yeni bir ordu kurmak amacıyla vali ve ayanları toplantıya çağırmış (meşveret-i amme) ve söz konusu toplantı sonucu Ekim 1808'de Sened-i İttifak ismiyle bir metin ortaya çıkmış, taraflar birbirlerine karşı taahhütlerini ${ }^{8}$ yeminle pekiştirmişlerdir (İnalcık, 1964: 603-606; Karal, 2011: 93). İttifakın vergiyle ilgili maddesi ise "Reayanın korunması esas olduğundan, hanedanların ve büyüklerin kendi idareleri altında olan kazaların asayişine ve vergilerin hadd-i itidale (mutedil) uygun olmasina dikkat etmeleri gerekir. Bunun için vükela ile hanedanlar arasında görüssme sonunda haksı vergilerin kaldırılması için verilecek kararların korunmasina dikkat edilecektir. Hanedanlar, birbirlerinin durumuna nezaret ederek zulüm yapanları, garaz gütmeksizin, devlete ihbar edip ittifakla zulmün önlenmesine çalışacaklardır” biçimindedir (İnalcık, 2012: 94; Velidedeoğlu, 1989; Akşin, 1994: 118). Bu bağlamda vergilerin mutedil olması, ödeme gücünü akıllara getirmekte, haksız ve soygun

seferiyye ve şer-i diğer senetlerden aldıklarl resimler, vergi yükünün artmasına sebep olmuştur (İnalcık, 2012: 177).

7 Bu durum, Sened-i İttifak'ın başlangıç kısmında “devlet yöneticileri arasında ve taşradaki hanedanlara soğukluk girmesi yüzünden düşmanlık ve anlaşmazlık durumları baş göstermiş olduğundan, yüce devletin gücü bölünmüş, içte ve dışta saygınlığı sarsılmış ve bu durumun, zengin ve fakir, yüksek ve aşağı bütün ümmetin güçsüzleşip bozulmasına neden olarak, gitgide ne çirkin sonuçlar doğurduğu ve hukuka aykırı olarak oluşan ve herkesçe bilinen rezaletler nedeniyle saltanatın temelinden batma derecesine vardı̆̆ı" ifadesiyle itiraf edilmektedir (Velidedeoğlu, 1989).

$8 \quad$ Bu taahhütler, şu şekilde özetlenebilir: Ayanlık babadan oğula geçen irsî bir görevdir, hanedan denilen büyük ayanlar ile diğer ayanlar arasinda bir hiyerarşi vardır, hanedanlar birbirlerini denetleyecek ve faaliyetleri ittifak halinde olacaktır, ceza hukuku alaninda adaleti sağlamak için keyfi müsadere son bulmakta, soruşturma ve "cümle indinde taayyün" usulleri getirilmektedir, yeni ordu hem merkezde hem de taşrada hanedanlarca kurulacak ve böylece hem merkezi hem adem-î merkezi olacaktır, sadrazamın pozisyonu güçlendirilmekle birlikte haksız davranışları olursa, hanedana direnme hakkı taninmaktadır (Akşin, 1994: 118). 
niteliğine bürünen vergi uygulamalarına son verilmek istenmektedir. Diğer yandan Alemdar Mustafa Paşa'nın yeniçeriler tarafından 15 Kasım 1808'de öldürülmesi nedeniyle Sened-i İttifak, uygulama alanı bulamamıştır.

II. Mahmut'un yeniçerilerle birlik olarak 1slahatçıları yok etmesiyle birlikte reform çalışmaları gündemden düşmüştür. Merkezi hükümet otoritesini yeniden sağlamak amacıyla ayanlara karşı başlatılan mücadele sonucu Yanya Ayanı Tepedelenli Ali Paşa 17 ay süren kuşatma sonucu öldürülmüş fakat Rum ve Yunan (1821) isyanlarında yeniçerilerin çaresizliği açık bir biçimde görülmüştür. Bunun üzerine Mısır valisi Mehmet Ali Paşa'dan yardım istenmiş ve 1826 'da yeniçeri ocağı kaldırılmıştır. II. Mahmut'un 30 Haziran 1839'da Mısır seferinde hayatını kaybetmesi üzerine yerine geçen I. Abdülmecit, III. Selim ile başlayan ve II. Mahmut ile devam eden reform çalışmalarını, Mustafa Reşit Paşa önderliğinde hazırlanan Gülhane Hatt-1 Hümayunu (3 Kasım 1839) ile sürdürmüştür. Bir 1slahat hareketi veya bir diğer deyişle "garplılaşma başlangıcı" (Abadan, 2012: 61) olan Hatt ile birlikte Padişah, tebasının yaşam, onur ve mal mülklerini garanti altına alarak, vergi takdir ve salınmasını bir sisteme bağlamakta ve askere alma ile birlikte eğitimde yeni yöntemler geliştirecek kuruluşların oluşturulmasını onaylamaktadır (Shaw ve Shaw, 1983: 91-2). Hatt'in genel itibariyle Batı tarzı yasaları benimseyerek, idari ve mali yapıda reform çalışmalarını modern bir tarzda sürdürme gayesinde olduğu ileri sürülebilir9 ${ }^{9}$. Nitekim devletin yıkılma aşamasına gelmesinin temel nedeni olarak gösterilen yasalardan uzaklaşma durumu, Hatt'da 'yüz elli yıldır, birbirlerini izleyen karışıklıklar ve çeşitli sebeplerle şeriata ve yüce kanunlarına uyulmadı̆̆ından, eski kuvvet ve refah, tam tersine zayıfllk ve fakirliğe dönüştü” ifadesiyle kabul edilmektedir. Gülhane Hatt-1 Hümayunu'nda yer alan vergiye ilişkin hükümler ise şu şekilde özetlenebilir ${ }^{10}$ :

"Devletin ve memleketin idaresi için bazı yeni kanunların konulması lüzumlu görülmüştür. Mevzu bahis olan kanunların başında can güvenliği, ırk, namus ve malın korunmasl, vergi toplanmast, halkın askere alınıp silahaltında tutulması süresi gibi hususlar gelmektedir... Vergilerin belirli olmast noktasına gelince, bir devlet, ülkesini korumak için askere ve gerekli diğer masraflara muhtaçtır. Bu, para ile olur. Para, tebaadan toplanacak vergiler ile oluştuğundan bunun en iyi şekilde toplanması gerekir. Eskiden bir gelir kaynağı sayılmış olan tek el (yedi vahit yani inhisar usulü) belasından kurtulmakla birlikte şimdiye kadar asla bir faydası görülmeyen yıkıcı iltizam

9 Hatt'ı Padişah adına yazan ve ilan eden Mustafa Reşit Paşa 'nın Avrupa'da uzun yıllar elçilik yapması ve bu dönemde Batı devlet anlayışını ve idaresini tanıyarak Imparatorluğun uluslararası durumunu yakından ögrenmesi, Hatt üzerinde kendisini göstermektedir (İnalcık, 2012: 102).

10 Hatt'ın literatürde çeşitli çevirileri olmakla birlikte çalışma, Halil İnalcık'ın 'Sened-i İttifak ve Gülhane Hattı Hümayunu” isimli çalışmasını referans almıştır. Halil İnalcık (1964), Sened-i İttifak ve Gülhane Hatt-ı Hüтауипи, Belleten, Cilt: XVIII, Sayl: 112, s.603-622. 
usulü hala sürmektedir. Bu usul, bir memleketin siyasi ve mali işlerini bir adamin keyfine ve hatta baskiss altina teslim etmek demektir. Bu adamin iyi bir karakteri de yoksa yalnız kendi çıkarına bakıp, her işi zulümden ibaret olacaktır. Bu sebeple, bundan sonra herkesin malına ve kudretine göre bir verginin belirlenerek kimseden bundan fazla bir şey alınmayacaktır. Devletin kara ve deniz askeri masrafları ile diğer giderlerini gerekli kanunlarla sinırlandırıp belli ederek, masraflar ona göre yapılacaktır... Can, $\imath \mathrm{rz}$, namus ve mal bahislerinde, ülkemizin bütün halkına şeriat kanunlarl gereğince teminat verilmiştir... Devlet ricali belirli günlerde toplanarak can ve mal emniyeti ve vergilerin belirlenmesi konularına dair gereken kanunlarl karar altına alacaklardır" (İnalcık, 1964: 604-605).

Gülhane Hatt'ının vergiye yönelik hükümlerinin genel olarak verimlilik, belirlilik, yasallık ve adalet gibi vergi ilkeleri çerçevesinde yoğunlaştı̆̆ görülmektedir. Özellikle "bundan sonra herkesin malına ve kudretine göre vergi alınması" ifadesi, verginin mali güce ya da bir diğer deyişle ödeme gücüne göre alınması, verginin toplumda adil dağılımını amaçlamaktadır ${ }^{11}$. Bu düşünce kapsamında daha önce II. Mahmut döneminde, yeniçeri ocağının yerine kurulan Asakir-i Mansure-i Muhammediye birliklerinin giderlerini karşılamak için şehirli tüccar ve atölye sahipleri üzerine konulan istihsal vergileri ile pazar vergileri kaldırılarak, tapu kadastro ve gelir tespiti üzerinden, ödeme gücüne dayalı ve artan oranlı vergilendirmeye geçilmek istenmiştir ${ }^{12}$. Bununla birlikte II. Mahmut'un 1939'da öldüğünde söz konusu tahrirler hala tamamlanamamış ve hedeflenen vergi sistemi uygulanamamıştır (Shaw, 1985: 934).

I. Abdulmecit döneminde, Gülhane Hatt-1 Hümayunu'nun ilanından birkaç ay sonra (24 Ocak 1839-19 Zilkade 1255) yayınlanan "talimat-1 seniyye" ile vergi reformu çalışmalarına devam edilmiştir. Söz konusu ferman ile vilayetlere "muhassıll-1 emval" ismiyle maaşlı memurlar gönderilmekte ve vergi ile ilgili işlemlerin muhassıllar eliyle gerçekleştirilmesi istenmektedir. Bu bağlamda "herkesin emlak ve arazi ve hayvanatına ve esnaf ve tüccar kisminin ylllk gelirlerine birer klymet takdir olunmak suretiyle ve binde hesablyla ... an-cema'tin tevzi olunan temettü vergisi” uygulamaya konulmaktadır (Sayın, 1999: 379). Söz konusu talimata göre muhassıllar, hazine defterlerinde kayıtlı olmayan gelirleri defterlere kayıt ederek merkeze gönderecek, gönderildikleri vilayetlerde öncelikli

11 Vergi reformunun bir diğer amacı ise Rusya (1806-1812, 1828-1829), Iran (1820-1828) ve Misır (1831-1833, 1838-1839) ile yapılan savaşların kamu maliyesi üzerindeki yıkıcı etkisinin (Pamuk, 2012: 101) azaltılmasıdır.

12 II. Mahmut, 8 Ağustos 1838 'de ülkenin nüfus ve varllk sayımlarının yapılmasını emrederek, ödeme gücüne göre vergi salınmast ilkesini getirmiştir. 23 Şubat 1839'da ise şeriat adına salınan tüm geleneksel vergiler, koyun vergisi (ağnam resmi) ve cizye dişında kaldırllmıştır. Toprak ürünlerine tek vergi olarak ürün değerinin onda biri üzerinden vergi salınmıştır. Pazar vergisiyle birlikte rüsumu sitte yerine tüccar ve zanaatkârların ödeme güçlerine göre bir temettüat vergisi getirilmiştir (Shaw ve Shaw, 1983: 130). 
olarak meclis ${ }^{13}$ kuracak, nüfus ve emlak tahrirlerini yapacak ve toplanacak verginin gecikmemesi için daha sonra mahsuplaşmak üzere mükelleflerden peşin vergi alarak hazineye gönderecektir (Kaynar, 1991: 235). Kurulacak mahalli meclislerin amacı ise reformların halkla paylaşılması ve böylece daha kolay benimsenmesi isteğidir (Şener, 2007: 78).

Çalışma, Tanzimatla birlikte uygulamaya konulan vergi reformunun bir aracı olarak Temettüat tahrirleri çerçevesinde, Osmanlı İmparatorluğu'nda gelir dağılımı ve göreli yoksulluğu, Sivas Eyaleti, Bozok Sancağı'na bağlı Sorgun Kazası örneğinde incelemektedir. Temettüat tahrirlerinden elde edilen hanehalkı verileri kullanılarak, Sorgun'da vergi öncesi ve vergi sonrası gelir dağılımı analiz edilmekte ve gelir dağılımı eşitsizliği Gini katsayısı ile ölçülmektedir.

\section{Temettüat Defterleri}

Verginin ödeme gücüne göre alınabilmesi için esas itibariyle ödeme gücünün tespitini amaçlayan temettüat tahrirleri, hanenin genel özelliklerinin yanı sıra sahip olunan servet stoku ve elde edilen gelire odaklanmaktadır. Böylece ödenecek vergi, hanelerin karakteristik özellikleri doğrultusunda belirlenerek, adil bir dağılım hedeflenecektir. $\mathrm{Bu}$ bağlamda "beyana dayanmamakla birlikte tahrire dayanan bir gelir vergisi" uygulamasına geçilmektedir (Şener, 2007: 118). Söz konusu vergi ise tahrir yoluyla belirlenen gelirin \%3’ü oranında tarh edilmektedir.

Talimat-1 Seniyye'nin dördüncü maddesi, nüfus ve emlak tahrirlerinde uyulacak usul ve esasları belirlemektedir. Buna göre her mahalde herkesin istisnasız isim ve şöhreti, ne kadar emlak, arazi ve hayvanı olduğu, bir yılda tahmini olarak ne kadar ticaret ve temettüatı olacağı belirlenecektir. Bu bağlamda "herkesin bir yll içinde ne düzeyde vergi ödeyeceği tespit edilerek, tek bir akçe fazla vergi alınmayacaktır” (Kaynar, 1991: 241).

Temettüat defterlerinin yazımı, tahriri yapılan eyalete bağlı sancak, kaza ve karye gibi bilgilerin verilmesiyle başlamaktadır. Hanelerin müslüman ve gayrimüslim olarak ayrıldığı defterlerde her bir hane, birden başlanılarak numaralandırılmakta ve daha sonra hane reisinin ismi, varsa lakabı ve mesleği verilmektedir. Hanede erkek bulunmaması durumunda ise hane reisi kadın olarak yazılmaktadır ${ }^{14}$. Hane reisinin gelire esas meslek

13 Bu meclisler, muhassıl ve iki kâtip, kadl, müftü, asker zabiti, gayrimüslimlerin bulunduğu yerlerde metropolit ve kocabaşıları ile yerel halktan seçilmiş dört kişi ve meclis başkanından oluşmaktadır (Kaynar, 1991: 238; Şenel, 2002: 29).

14 Örneğin, Yozgat Sancă̆l, Sorgun Kazası, Karapınar Karyesi, 14 hane numaralı hane reisi "Hacı Mehmed'in Halilesi Arzu Hatun" biçiminde kaydedilmiştir. 
bilgisi ise ziraatçı, çoban, azab, tüccar, değirmenci, imam vb. biçiminde yer almaktadır. Ödeme gücü olmayan haneler ise "muhtaç" olarak kaydedilmektedir. Hanenin bir önceki yıl ödediği vergi miktarı da bu kısımda ayrıca belirtilmektedir. Bununla birlikte babasından bir gelir unsuru miras kalanlar, "yetim" olarak yazılmakta, geliri bulunmayan yetimler ile yaşlı, kör, mecnun ve benzeri kimseler ise muaf olarak kaydedilmektedir (Adiyeke, 2000: 780-2). Hane reisinin isim ve meslek bilgilerinin altında ise sahip olunan gayrimenkuller yer almaktadır. Buna göre hanelerin tarla, bahçe, bostan gibi gelir elde ettiği unsurlar ayrıntılı bir biçimde sıralanmakta ve nasıl tasarruf edildiği (boş, kirada gibi) belirtilerek, öşrün tespiti için de ürün miktarı ve değeri yazılmaktadır ${ }^{15}$. Ev ve dükkân gibi diğer gayrimenkul unsurları ise gelire konu olup olmamasına göre ayrıca belirtilmektedir. Hanelerin sahip olduğu ve gelir elde ettiği hayvanlar ise sağman inek, sağman camus, koyun, merkep, tosun, oğlak, koşu mandası ve arı kovanı biçiminde kaydedilerek, sayılarıyla birlikte sağlanan gelir düzeyi belirtilmektedir (Kütükoğlu, 1995: 405-9). Diğer yandan hanenin elde ettiği ek gelirler de toplama dâhil edilmekte ve vergilendirilmektedir ${ }^{16}$.

Tarım ürünleri için 1844 yılı hasılası, her bir ürün için ödenen öşrün, mahsullerin birim fiyatlarıyla çarpılması sonucu ulaşılan değerin on katı dikkate alınarak hesaplanmıştır. Üretim için yapılan giderler ise hasılattan düşülmediği için gelir, gayrisafidir ${ }^{17}$. Üretimde ücretlilerin çalıştırılması durumunda ise ödenen ücret, gayrisafi hasılattan düşülmektedir. Tarlanın kiralanması (icar) durumunda ise kira geliri tarla sahibine, gayrisafi hasılat ise kiracı üzerine kaydedilmektedir. Hayvanlar üzerinden elde edilen gelirler ise belirlenen hâsıla tarifeleri yardımıyla tespit edilmiştir (Güran, 1987: 297; 2000: 78). Tablo: 1'de Sivas eyaletine bağlı, Yozgat Sancağı, Sorgun Kazası, Çavuşlu Karyesine ilişkin bir temettüat tahrir örneği gösterilmektedir.

15 1840-41 temettü tahrirlerinde ise söz konusu unsurların yüzölçümleri dikkate alınmışstr (Kütükoğlu, 1995: 405).

16 Örneğin, hane reisinin tımarlı zaptiye olması nedeniyle toplam gelire 1.800 kuruş, bașka bir hanenin oğlunun azab olması nedeniyle 100 kuruş dâhil edildiği görülmüsstür (Polat, 2010). Benzer biçimde sahip olunan katır ve eşek ile nakliyatçılık yapılarak elde edilen hasılat, toplam gelire dâhil edilmektedir (Adiyeke, 2000: 774).

17 Örneğin Nuri Adlyeke tarafindan, temettüat sayımlarını düzenleyen nizamname örnekleri üzerine yapılan incelemede referans verilen B.O.A., A. DVN. 13/44 numaralı nizamnamede yer alan bir soruda, kiraya verilen bir değirmen için yapılan bakım ve onarım giderinin elde edilen hasılattan indirilip indirilmeyeceği, verilen cevapta ise yapılan masrafların kira gelirinden düşülmeyeceği, kira tutarının toplam olarak yazılması gerektiği belirtilmektedir (2000: 801). Bunun nedeni ise "gerçek geliri bulalım derken ahalinin mazbut olan mizaç ve tavırlarının bozulacağı ve ahalice dedikodulara sebep olması"dır (2000: 773). 
Tablo: 1

Sivas Eyaleti, Bozok Sancağı Kaymakamlığı, Sorgun Kazası Çavuşlu Karyesi Ahali-i İslamın Emlâk ve Arâzi ve Temettuatı

\begin{tabular}{|c|c|c|c|c|c|c|c|c|c|c|c|c|c|c|c|c|c|c|c|c|c|c|c|c|c|c|}
\hline \multirow[b]{2}{*}{ 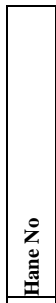 } & \multicolumn{2}{|l|}{$\begin{array}{l}\text { SANCAK: YOZGAT } \\
\text { KAZA: SORGUN } \\
\text { KARYE: ÇAVUŞLU }\end{array}$} & \multirow{2}{*}{ 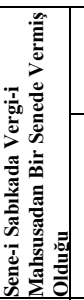 } & \multicolumn{7}{|c|}{$\begin{array}{c}\text { A'ŞAR ve RÜSUMAT OLARAK } \\
\text { VERMISS OLDUĞU }\end{array}$} & \multirow[b]{2}{*}{ 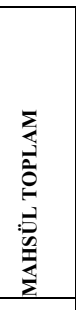 } & \multirow[b]{2}{*}{ 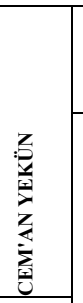 } & \multicolumn{4}{|c|}{ MEZRU TARLA } & \multicolumn{2}{|c|}{ 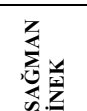 } & \multicolumn{2}{|c|}{ 永 } & \multirow[b]{2}{*}{ 忑 } & \multirow[b]{2}{*}{\begin{tabular}{l}
3 \\
$\vdots$ \\
\hdashline \\
\hdashline
\end{tabular}} & \multirow[b]{2}{*}{ 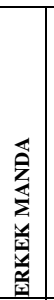 } & \multirow[b]{2}{*}{ 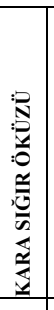 } & \multirow[b]{2}{*}{ 思 } & \multirow{2}{*}{ 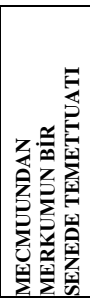 } \\
\hline & NO: 14390 & & & تَّت & & 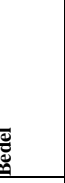 & हี & : & ڤ્ઁّ & है & & & & & & 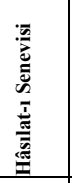 & & 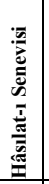 & & 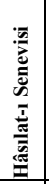 & & & & & & \\
\hline & İsim & Meslek & 咅 & $\stackrel{\square}{\frac{\pi}{2}}$ & 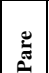 & 雍 & 尝 & $\stackrel{\varrho}{\bar{\Sigma}}$ & 䇺 & 管 & 兽 & 望 & 范 & 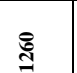 & $\vec{\Xi}$ & 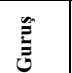 & $\begin{array}{l}\infty \\
\ddot{0}\end{array}$ & 竧 & $\begin{array}{l}\infty \\
\approx \\
\approx\end{array}$ & 离 & $\ddot{\ddot{g}}$ & $\stackrel{n}{\ddot{g}}$ & $\ddot{\ddot{g}}$ & $\ddot{\ddot{\ddot{n}}}$ & $\infty$ & Guruș \\
\hline 1 & Bezgin (?) oğlu Ali Bölükbas1 & Ziraatc & 100 & 5 & 30 & 3 & 18,75 & 4 & 2 & 8 & 26,75 & 26,75 & 15 & 238,5 & 150 & 388,5 & 1 & 8 & 1 & 10 & & & & 2 & 1 & 256,5 \\
\hline 2 & Kel İbiș & Ziraatc1 & 150 & 12 & 30 & 3 & 45 & 8 & 2 & 12 & 61 & 61 & 25 & 549 & 400 & 949 & 2 & 16 & & & 1 & 1 & 1 & & 1 & 565 \\
\hline 3 & Demirci oğlu Halil & Ziraatc1 & 100 & 8 & 30 & 3 & 30 & 5 & 2 & 10 & 40 & 40 & 15 & 360 & 300 & 660 & 1 & 8 & & & 1 & & & 2 & 1 & 368 \\
\hline 4 & Demirci oğlu Kara Ahmed & Ziraatc1 & 80 & 8 & 30 & 3 & 30 & 6 & 2 & 12 & 42 & 42 & 15 & 378 & 260 & 638 & 1 & 8 & & & 1 & & & 2 & & 386 \\
\hline 5 & Kirpiği Sarı oğlu Ahmed & Ziraatc1 & 150 & 12 & 30 & 3 & 45 & 8 & 2 & 16 & 61 & 61 & 20 & 549 & 400 & 949 & 2 & 16 & 1 & 10 & & 1 & & 1 & 1 & 575 \\
\hline & Toplam & & 580 & 45 & 150 & 15 & 168,75 & 31 & 10 & 58 & \begin{tabular}{l|l}
230,75 \\
\end{tabular} & 230,75 & 90 & 2074,5 & $\begin{array}{l}1510 \\
\end{array}$ & 3584,5 & 7 & 56 & 2 & 20 & 3 & 2 & 1 & \begin{tabular}{l|}
7 \\
\end{tabular} & 4 & 2150,5 \\
\hline
\end{tabular}

Kaynak: Serkan Polat (2010) Temettüat Defterlerine Göre Sorgun Kazasının Sosyo-Ekonomik Yapısı, Yayınlanmamış Yükseklisans Tezi, s. 146. 


\section{Literatür}

Literatürde temettüat defterleriyle ilgili çalışmalar incelendiğinde, temettüat defterlerinin 1988 yılında kataloglanarak araştırmacılara açılmasından önce, Prof.Dr. Tevfik Güran tarafından kullanıldığı görülmektedir. 1979 yılında Fransızca olarak yayınladığ $1^{18}$ çalışmada Güran, Filibe Sancağının Koyuntepe nahiyesine bağlı dokuz köy üzerinde ekonomik ve sosyal yapı üzerine karşılaştırmalı bir analiz gerçekleştirmiştir. Benzer biçimde 1985 tarihli "Ondokuzuncu Yüzyıl Ortalarında Ödemiş Kasabasının Sosyo-Ekonomik Özellikleri” ile 1987 tarihli "Osmanlı Tarım Ekonomisi, 1840-1910" başlıklı temettüat çalışmaları, literatürde yer almaya başlamıştır. Bununla birlikte defterlere yeteri düzeyde ilgi gösterilmemesi nedeniyle Mübahat Kütükoğlu (1995) tarafından "Osmanlı Sosyal ve İktisâdi Tarihi Kaynaklarından Temettü Defterleri” başlıklı bir çalışma yayınlanmış ve temettüat defterlerini tahrir defterleriyle karşılaştırarak, araştırmacılara tanıtmayı amaçlamıştır (1995: 396). 1999 yılı çalışmasında ise Kütükoğlu, İzmir temettüat sayımları kapsamında İzmir'de yaşayan yabancı nüfusun sosyo-ekonomik özelliklerini incelemiştir. Diğer yandan Güran (2000) "XIX. Yüzyıl Temettüat Tahrirleri” çalışmasıyla, defterler üzerindeki akademik çalışmaların yetersizliğini vurgulayarak, temettüat defter koleksiyonunun kapsam ve özelliklerini tanıtmaktadır (2000: 75). Said Öztürk, "XIX. Yüzyılda Söğüd'ün Sosyo-Ekonomik Yapısı" (1995) ve "Tanzimat Döneminde Bir Anadolu Şehri Bilecik" (1996) isimli çalışmalarında temettüat defterleri verilerinden yararlanmıştır. Nuri Adıyeke (2000) temettüat sayımlarıyla ilgili usul ve esasları araştırarak, sayımları düzenleyen üç adet nizamname örneğini incelemiştir. Akgündüz ve Öztürk ise Yozgat temettüat defterlerini üç cilt olarak yayınlamışlardır (2000).

Temettüat defterleri, araştırmacılara hane düzeyinde bilgi sağlaması nedeniyle, literatürde özellikle çeşitli bölgelerin sosyo-ekonomik analizlerine yönelik çalışmalar yaygın bir biçimde yer almaktadır. Yalçın (2004) Temettüat defterleri kapsamında Silifke Kazasını, Efe (2006) Eskişehir'e bağlı Çukurhisar Köyünü, Bozkurt (2011) Kütahya Sancağını Dazkırı Kazasına bağlı Bolatlı Köyünü, Şenel (2002) Ankara eyalet merkezini, Polat (2010) Sivas Eyaleti Bozok Sancağı Sorgun Kazasını, Tekin (2012) Turgutlu Kasabasını, Cengiz (2010) Ankara'ya bağlı Pursaklar Köyünü, Taşkaya (2013) Kütahya Sancağı Gediz Kasabasına bağlı Şaphane Köyünü, Muşmal (2008) Konya Vilayeti Merkez Kazasına bağlı Çumra Köyünü, Değerli (2013) Beyşehir Sancağına bağlı Seydişehir Kazasını, Öztürk ve Atam (2011) Priştine'yi ve Geçer ise (2012) Konya Vilayeti İçel Sancağına bağlı Mut Kazasını incelemişlerdir. Diğer yandan Gökmen (2008) temettüat

18 Tevfik Güran (1979) Etude Comparee De Neuf Villages De La Nahiye De Koyuntepe, Sanjak De Filibe, in: Structure Economique et Sociale d'une Region de Campagne dans l'Empire Ottoman Vers le Milieu du XIXe.s, Eds., Sofya, Sofia. 
defterlerinden yararlanarak Saruhan Sancağı temettüat tahrirlerini incelemiş, Şener ise (2008) Osmanlı kırsalında ekonomik ve sosyal yapıyı analiz etmiştir.

Güran (1985) tarafından gerçekleştirilen "Ondokuzuncu Yüzyıl Ortalarında Ödemiş Kasabasının Sosyo-Ekonomik Özellikleri” isimli çalışmada temettüat defterleri kullanılarak, hanelerin meslekleri, gelir kaynakları, gelir dağılımı ve vergi yükü gibi unsurlar incelenmiş̧ir. Kasabanın dört müslüman mahallesinde toplam 594 hanenin 123’ü $(\% 20,7)$ tarım kesiminde rrgat olarak çalışırken, 84'ü $(\% 14,1)$ mal ve hizmet üreten esnaf kapsamında urgancıdır. 60 hanenin $(\% 10,1)$ ziraatla uğraştı̆̆ı, 24 hanenin $(\% 4)$ yine tarımla ilgili olarak rençberlik yaptığı, 62 hanenin ise $(\% 10,4)$ yaşl1, çocuk ve kadınlardan oluştuğu belirlenmiş̧ir. Gelirin haneler arası dağılımında ise toplam hanelerin \%14,1'ini oluşturan çiftçi ve rençber grubunun toplam gelirin \%19,9'unu, hanelerin \%24,1'ini oluşturan 1rgat, hizmetkâr ve çoban gibi tarım işçilerinin toplam gelirin \%17,6'sını elde ettiği bulunmuştur. Hanelerin \%42,9'unu oluşturan esnaf ve tüccarlar toplam gelirin \%47,1'ini, hanelerin $\% 0,9$ 'unu oluşturan rant geliri elde edenler toplam gelirin $\% 6,2$ 'sini ve yaşlı, çocuk ve kadınlar ise $\% 9,2$ 'sini almaktadır.

Ergene ve Berker (2008), XVIII. Yüzyıl Kastamonu mahkeme kayıtları (sicil) üzerinden müslüman toplum için servet ve eşitsizlik analizi yapmışlardır. Buna göre 17121760 yılları arasında yedi yüz yetmiş sekiz sicil kaydı kullanılarak tereke kayıtları incelenmiştir. Nafaka davalarından elde edilen verilere göre yetişkin bir kadının alacağ nafaka tutarı, kadının sosyal ve ekonomik durumuna göre dokuz akçe ile yirmi bir akçe ${ }^{19}$ arasında değişmektedir ${ }^{20}$. Bu bağlamda çalışma, XVIII. yüzyıl başlarında yalnız bir kadın için yoksulluk sınırını yıllık otuz kuruş, yalnız bir erkek için ise elli kuruş olarak hesaplamıştır (2008: 27). Coşgel ve Ergene ise (2012) benzer biçimde XVIII. yüzyıl Kastamonu mahkeme kayıtlarını kullanarak çeşitli dönemler itibariyle servet farklılıklarını araştırmışlardır. Buna göre Kastamonu'da 1713-1802 yılları arasında Gini katsayısı 0,60 olarak belirlenmiştir. Diğer yandan servet eşitsizliği aynı dönemde artmış ve bu durum istatistiksel olarak anlamlı bulunmuştur (2012: 328).

Cankabal ve Filiztekin (2013) ise Osmanlı İmparatorluğu'nda servet ve eşitsizlik kavramlarını incelemişlerdir. 1500-1840 yılları arasındaki döneme ilişkin Osmanlı vasiyet sicillerinin kullanıldığ çalışma, Anadolu'da Bursa, Manisa, Kayseri, Antep, Trabzon ve Diyarbakır'ı, Makedonya'da ise Manastır/Bitola'yı kapsamaktadır. 11.098 sicile ilişkin

19 İstanbul Kadı Sicilleri üzerine yaptı̆̆ımız araştırmada ise yalnız bir kadına verilen nafakanın 1520 'lerde günlük bir, bir buçuk ve iki akçe, 1618 'de ise üç akçe olduğu tespit edilmiştir. Çocuk için verilen nafaka miktart ise iki akçe ile on akçe arasında değişmektedir.

20 1710-1719 yılları arasındaki on yıllık dönem için İstanbul'da düz işçilerin günlük ücreti 25,2 akçe iken vasıflı işçiler için bu tutar 38,2 akçedir. 1750-1759 yılları arasındaki on yıllık dönem için ise söz konusu tutarlar straslyla 32,4 ve 58,6 akçe olarak hesaplanmıştır (Pamuk, 2013: 166). 
kararların incelendiği çalışmaya göre, eşitsizliğin en fazla görüldüğü şehir Bursa'dır. 15001600 arası dönemde 0,70 'ler düzeyinde seyreden Gini katsayısı, $1700-1720$ arasında 0,80 ' $\mathrm{i}$ aşmış, 1740-1840 arasında ise yine 0,70'in üzerinde gerçekleşmiştir. XVIII. yüzyılda Bursa, Manisa ve Kayseri'de eşitsizlikle birlikte Gini katsayısının arttığ 1 tespit edilmiştir. Buna göre Bursa ve Manisa'da 1820-1840 arası dönem için Gini katsayısı 0,70'in üzerinde, Diyarbakır ve Kayseri'de ise 0,60'ın üzerinde hesaplanmıştır. Sonuç olarak çalışmada Kastamonu, Manisa ve Kayseri eşitsizlik göstergelerinin Amerika Kolonileri ile benzerlik gösterdiği tespit edilmiştir.

Morrison ve Snyder (2000) XVIII. ve XIX. yüzyıllarda Fransa gelir eşitsizliğini tarihsel perspektifle analiz etmişlerdir. Fransa'nın endüstriyel gelişimiyle birlikte gelir dağılımının nasıl değiştiğine odaklanan çalı̧̧ma, anılan yüzyıllara ilişkin vergi verilerini kullanmıştır. Çalışmadan elde edilen sonuca göre Fransa'da XVIII. yüzyılda gelir eşitsizliğinin oldukça yüksek olduğu tespit edilmiştir. Buna göre 1780'de Gini Katsayısı 0,60/0,62'dir. Bununla birlikte sanayileşme sonucunda gelir eşitsizliğinin XIX. yüzyılda azaldığ 1 ve Gini Katsayısının 0,48'e gerilediği belirlenmiştir. Soltow ise (1983) benzer bir yöntemle Kentucky/Philadelphia'da 1800 ve 1860 yılları için vergi listelerini kullanarak servet dağ 1 lımını incelemiştir. 1800'den 1840'a kadar olan dönemde servet gelişimi yıllık $\% 2,4,1840-1860$ arası dönemde ise yıllık \%2,8'dir. Bununla birlikte söz konusu gelişimin özgür erkekler için eşit olmadığı tespit edilmiştir. Nitekim 1800 ve 1860 yıllarının her ikisinde de özgür erkekler için Gini katsayısı 0,80'dir. Lindert (2000) Britanya ve Amerika için gelir ve servet eşitsizliğini incelemiş ve Amerika'da 1774 ile 1913 arasında gelir ve servet dağılımı arasındaki açığın genişlediğini, Britanya'da ise 1740'dan 1810'a kadar eşitsizliğin arttı̆̆ını tespit etmiştir. Lindert ve Williamson (2012) tarafından 1774-1860 dönemi, Amerika gelir düzeyi üzerine yapılan çalışmada ise İngiltere ve Galler için Gini katsayis1 1759 'da $0,522,1802$ 'de 0,593 , Hollanda için 1732 'de 0,610 ve 1808 'de 0,563 olarak hesaplanmıştır.

\section{Veri ve Yöntem}

Emlak, arazi, hayvanat ve temettüat tahrirleri kapsamında oluşturulan temettüat defterleri, Başbakanlık Osmanlı Arşivi Maliye Varidat Temettüat (BOA. ML. VRD. TMT.d) kataloglarında yer almaktadır. Dokuz katalog içinde 1256-1261 (1840-1845) yıllarına ait toplam 17.747 defter bulunmakla birlikte defterlerin büyük çoğunluğu 1844-1845 yıllarına aittir. $\mathrm{Bu}$ bağlamda temettüat tahrirlerinde yaklaşık olarak 1,1 milyon hanenin yer aldığ tahmin edilmektedir. Kataloglarda Ankara, Aydın, Bolu, Cezair-i Bahr-i Sefid, Edirne, Erzurum, Hüdavendigar, Konya, Niş, Rumeli, Selanik, Silistre, Sivas, Üsküp ve Vidin'e ilişkin temettüat defterleri bulunmaktadır (Başbakanlık, 2010: 248). Bununla birlikte defterlerin bir kısmı ise Kamil Kepeci ve Maliyeden Müdevver Defterler sınıflandırması içindedir (Güran, 2000: 76-79). 
Çalışmada kullanılan veriler ise Sorgun Belediyesi tarafından üç cilt olarak yayınlanan" ${ }^{21}$ "Sorgun Temettuat Defterleri"nden derlenmiştir. Buna göre Sivas Eyaleti, Sorgun Kazasına bağlı seksen sekiz mahalin ${ }^{22}$ temettüat defteri ${ }^{23}$ transkripsiyonu yapılarak, aslına uygun biçimde yayınlanmıştır. 1260-1261 (1844-1845) yıllarına ait olan Sorgun temettüat defterlerine göre çalışmanın kapsamı, Sorgun Kazasına bağlı köylerde ikamet eden 1.908 haneden oluşmaktadır. Osmanlı İmparatorluğu'nda 1831 yllında gerçekleştirilen nüfus sayımında ise Sorgun Kazasında 8.573 müslüman erkek bulunmakta, gayrimüslim ise yer almamaktadır (Karal, 1995: 154). Bununla birlikte temettüat defterlerinde gayrimüslim hanelerin yer aldığı görülmektedir. Köhne-i Kebir, kayıtlı doksan müslüman ve yirmi dokuz gayrimüslim hane ile en kalabalık köydür. Defterlerden elde edilen veriler, hanelerin, hane reisi isimleri, meslekleri, yıllık gelirleri, sahip oldukları emlak, arazi ve hayvanlar ile tabi oldukları mali yükümlülükleri göstermektedir. Örneğin tarım ile uğraşan haneler "erbab-l ziraatten idiği, erbab-ı ziraat veya ziraatçı" olarak kaydedilirken diğer meslek unsurları ise "çoban, bakkal, azab, keşiş vb." isimlerle anılmıştır. Diğer yandan herhangi bir geliri olmayanlar ise "başıboş" ya da "amel-mande" gibi isimlerle kaydedilmiş ve "şunun bunun ianesiyle geçinmekte" olduğu belirtilmiştir. Tarımsal faaliyet sonucu elde edilen mahsuller ise kile olarak kaydedilmiş ve bu yolla ödenecek öşür ile birlikte hasılat belirlenmiştir. Ödenecek vergi her bir ürün için belirlenen birim fiyat üzerinden hesaplanmıştır. Örneğin söz konusu fiyat, buğday için üç kuruş otuz para iken burçak için iki kuruştur. Hanelerin hayvancılık yoluyla elde ettiği gelirler ise yine hayvan başına belirli bir miktar olarak belirlenmiş ve hayvan sayısıyla çarpılmıştır. Örneğin sağman inek sekiz kuruş ve sağman camus on altı kuruşken, taşımacılıkta kullanılan döllü merkep on kuruş, döllü kısrak elli kuruş ve döllü deve ise iki yüz kuruş olarak tespit edilmiştir.

21 Söz konusu yayın, esas itibariyle Serkan Polat (2010) tarafindan hazırlanan "Temettuat Defterlerine Göre Sorgun Kazasının Sosyo-Ekonomik Yapısı" isimli yayınlanmamış yüksek lisans tezine dayanmaktadır. Bu bağlamda çalı̧̧mada, adı geçen yüksek lisans tezinden, yazarın izni alınarak yararlanılmıştır.

22 Inceleme konusu yerleşim yerlerinin listesi Ek: 1'de gösterilmektedir.

23 Sorgun Kazasına ait transkripsiyonu yapılan temettüat defterleri şunlardır: Başbakanlık Osmanlı Arşivi, Maliye Varidatı Temettüat Defterleri, Sorgun Temettüat Defteri, No: 14308, 14309, 14310, 14311, 14312, 14313, 14314 , $14315,14316,14317,14318,14319,14321,14323,14324,14325,14326,14327,14328,14329,14330,14333$, $14334,14335,14336,14337,14338,14339,14340,14341,14342,14343,14345,14347,14348,14349,14350$, $14351,14352,14353,14354,14357,14359,14360,14361,14362,14363,14364,14365,14366,14367,14368$, $14369,14370,14371,14372,14373,14374,14375,14376,14377,14378,14379,14380,14381,14382,14383$, 14384, 14386, 14387, 14388, 14389, 14390, 14392, 14393, 14395, 14396, 14398, 14399, 14401, 14403, 14404, 14619, Kamil Kepeci: Sorgun Temettüat Defteri (Varidat Muhasebeciliği), Gömlek No: 6053, C.DH: Dosya No: 161, Gömlek No: 8019, İrade Dâhiliye (İ.DH), nr.15/707, 10 Haziran 1840 tarihli tahrirat, MAD.d: Gömlek No: 22122 . 
Tablo: 2

Tanımlayıcı İstatistikler

\begin{tabular}{|l|c|c|c|c|c|}
\hline & Gözlem & Ortalama & St. Sapma & En Az & En Çok \\
\hline Hane & 1.908 & 954,5 & 550,9365 & 1 & 1.908 \\
\hline Gelir & 1.908 & 566,9269 & 402,1487 & 0 & 3346,75 \\
\hline Vergi-i Mahsusa & 1.908 & 104,0489 & 76,51682 & 0 & 640 \\
\hline Aşar ve Rüsumat & 1.886 & 56,00736 & 38,88144 & 0 & 262,5 \\
\hline
\end{tabular}

Literatürde farklı yoksulluk tanımları ve sınırları bulunmakla birlikte çalışmada göreli yoksulluk ${ }^{24}$ sınırları kullanılmaktadır. Bunun en önemli nedeni mutlak yoksulluk sınırlarının, toplumun göreli olarak kıyaslanmasına olanak vermemesidir. Bu bağlamda toplumun genel düzeyine göre belirli bir sınırın altında gelir veya harcamaya sahip olan birey veya hanehalk1 göreli anlamda yoksul sayılmaktadır (Foster 1998; Zaidi, 1992; Pradhan \& Ravallion, 2011; Ravallion, 1998). Çalışmada kullanılan göreli yoksulluk sınırı, medyan gelirin \%50'si kullanılarak bulunmaktadır. Buna göre söz konusu sınırın altında bir gelir düzeyine sahip olan haneler, göreli olarak yoksuldur. Diğer yandan gelir eşitsizliğinin düzeyi ise Gini Katsayısı ile belirlenmektedir. Buna göre Gini Katsayısı, Lorenz Eğrisi ile mutlak eşitlik doğrusu arasındaki alan ile mutlak eşitlik doğrusunun altındaki alanın birbirine oranlanmasıyla elde edilmektedir. Sıfır ile bir arasında değişen Gini Katsayısının sıfıra yaklaşması gelir dağılımını iyileştirirken bire yaklaşması ise gelir dağılımını bozmaktadır. Literatürde Gini Katsayısı (G) aşağıdaki gibi gösterilmektedir (Brown, 1994);

$\mathrm{G}=1-\sum_{i=0}^{k-1}((Y i+1+Y i)(X i+1+X i)$

G : Gini Katsayıs1

$Y_{i}:$ Sağlık değişkeninin kümülatif dağılımı

$X_{i}:$ Nüfus değişkeninin kümülatif dağılımı

24 Hane ya da bireylerin yaşamlarını fiziksel olarak sürdürebilmeleri için ihtiyaç duyulan minimum tüketim seviyesi, mutlak yoksulluk olarak tanımlanmaktadır. Bu nedenle, mutlak yoksulluğun ortaya çıkarılması, bireylerin yaşamlarını sürdürebilmeleri için gerekli olan minimum tüketim ihtiyaçlarının belirlenmesini gerektirir. Mutlak yoksulluk gıda ve glda dişı bileşenler dikkate alınarak ayrı ayrı belirlenebilmektedir. Mutlak yoksulluk oranı, asgari refah düzeyini yakalayamayanların sayısının toplam nüfusa oranıdır. Göreli yoksulluk ise toplumun genel düzeyine göre belli bir sınırın altında gelir ve harcamaya sahip olan birey veya hanehalkı göreli anlamda yoksul olarak tanımlanır. Refah ölçüsü olarak amaca göre tüketim veya gelir düzeyi seçilebilir (TÜIK, 2011). 


\section{Bulgular}

Sivas Eyaleti, Bozok Sancağı, Sorgun Kazasına ait temettüat defterlerinin transkripsiyonu kapsamında elde edilen veriler, hanelerin bir yıl boyunca elde ettiği gelire odaklanmaktadır. Bu kapsamda sahip olunan emlak ve hayvan ile birlikte hane tarafindan yürütülen diğer faaliyetler, defterlerde ayrıntılı olarak yer almaktadır. Buna göre hane reislerinin \%84,6's1 çiftçi, \%4,4'ü azab ${ }^{25}$, \%4'ü çoban ve \%7'si ise diğer mesleklerden oluşmaktadır. Sorgun Kazasında yaşayan gayrimüslim kırk dört hanenin yirmi beşi sanayi ve ticaretle ${ }^{26}$, on ikisi ise tarımla uğraşmaktadır. Elde edilen toplam gelirin yaklaşık olarak \%94'ü çiftçilere aitken, azablar toplam gelirin \%1,5'ini, çobanlar ise \%1,3'ünü almaktadır. Çiftçiler için yıllık ortalama gelir 630,6 kuruş, azablar için 201,4 kuruş, hizmetkârlar için 173,8 kuruş ve çobanlar için ise 201 kuruş olarak tespit edilmiştir. Söz konusu tutar muhtaçlar için yıllık 6 kuruştur. Hanelerin \%2,1'i yıllık 250 kuruşun altında, \%51,4'ü ise yıllık 500 kuruşun altında gelir elde ederken, \%12,4'ü yıllık 1.000 kuruşun üzerinde, $\% 0,7$ 'si ise 2.000 kuruşun üzerinde gelir elde etmektedir. 3.000 kuruş üzerinde gelir elde eden hane sayısı ise iki olup 2.000 kuruşun üzerinde gelir elde edenlerin tamamı çiftçidir.

Tablo: 3

\section{Sorgun Kazasında Nüfusun \%20'lik Dilimler İtibariyle Gelirden Aldığı Pay}

\begin{tabular}{|l|c|c|}
\hline Gelir Dilimleri & Gelirden Alınan Pay (\%) & Kümülatif Toplam (\%) \\
\hline Birinci \%20'lik Dilim & 4,6 & 4,6 \\
\hline İkinci \%20'lik Dilim & 11,4 & 16 \\
\hline Üçüncü \%20'lik Dilim & 17,4 & 33,4 \\
\hline Dördüncü \%20'lik Dilim & 24,6 & 58 \\
\hline Beşinci \%20'lik Dilim & 42 & 100 \\
\hline
\end{tabular}

Kaynak: Sorgun Temettüat Defterleri, 1844-1845.

Sorgun Kazasında yer alan 1.908 hanenin bir yıl boyunca elde ettiği gelir ve bu gelirin söz konusu haneler arasındaki dağılımı Tablo: 3'de, Lorenz Eğrisi ise Grafik 1'de gösterilmektedir. Buna göre nüfusun en yoksul birinci \%20'lik diliminde yer alan haneler, toplam gelirin \%4,6'sını alırken, ikinci \%20'lik dilim \%11,4'ünü ve üçüncü \%20'lik dilim ise \%17,4'ünü almaktadır. Orta gelir düzeyinin üzerinde yer alan dördüncü \%20'lik dilim, toplam gelirin \%24,6'sını almakta ve nihayet en zengin beşinci \%20'lik dilimde yer alan haneler ise \%42'sini elde etmektedir. Bu bağlamda en zengin dilimde yer alan haneler ile en yoksul dilimde yer alan haneler arasındaki gelir farkı yaklaşık olarak dokuz kattır. Birinci dilimde yer alan hanelerin yıllık ortalama geliri 130 kuruş iken en zengin beşinci dilimde yer alan hanelerde ise bu tutar 1.188 kuruş olarak belirlenmiştir. Diğer yandan söz konusu

25 Bekâr erkek anlamına gelen azab, savaşta ordunun en önünde yer alan gönüllü askerlerdir.

26 Demirci, terzi, boyacı, çerçi, köşker, köşker çırağl, dikici, bakkal ve kalaycıların tamamı gayrimüslimdir (Polat, 2010: 68). 
ortalama gelir, ikinci, üçüncü ve dördüncü \%20'lik dilimler için sırasıyla 326, 494 ve 700 kuruştur. Toplam gelirin haneler arasında dağılımına ilişkin olarak hesaplanan eşitsizlik endeksleri ile göreli yoksulluk oranı Tablo: 4'de yer almaktadır.

Tablo: 4

\section{Sorgun Kazasında Gini Katsayısı ve Göreli Yoksulluk Oranı}

\begin{tabular}{|l|c|c|}
\hline & Vergi Öncesi & Vergi Sonrası \\
\hline Gini Katsayıs1 & 0,3743 & 0,4031 \\
\hline Göreli Yoksulluk Oranı & 0,2007 & 0,3100 \\
\hline
\end{tabular}

Kaynak: Sorgun Temettüat Defterleri, 1844-1845.

Grafik: 1

Sorgun Kazası Lorenz Eğrisi

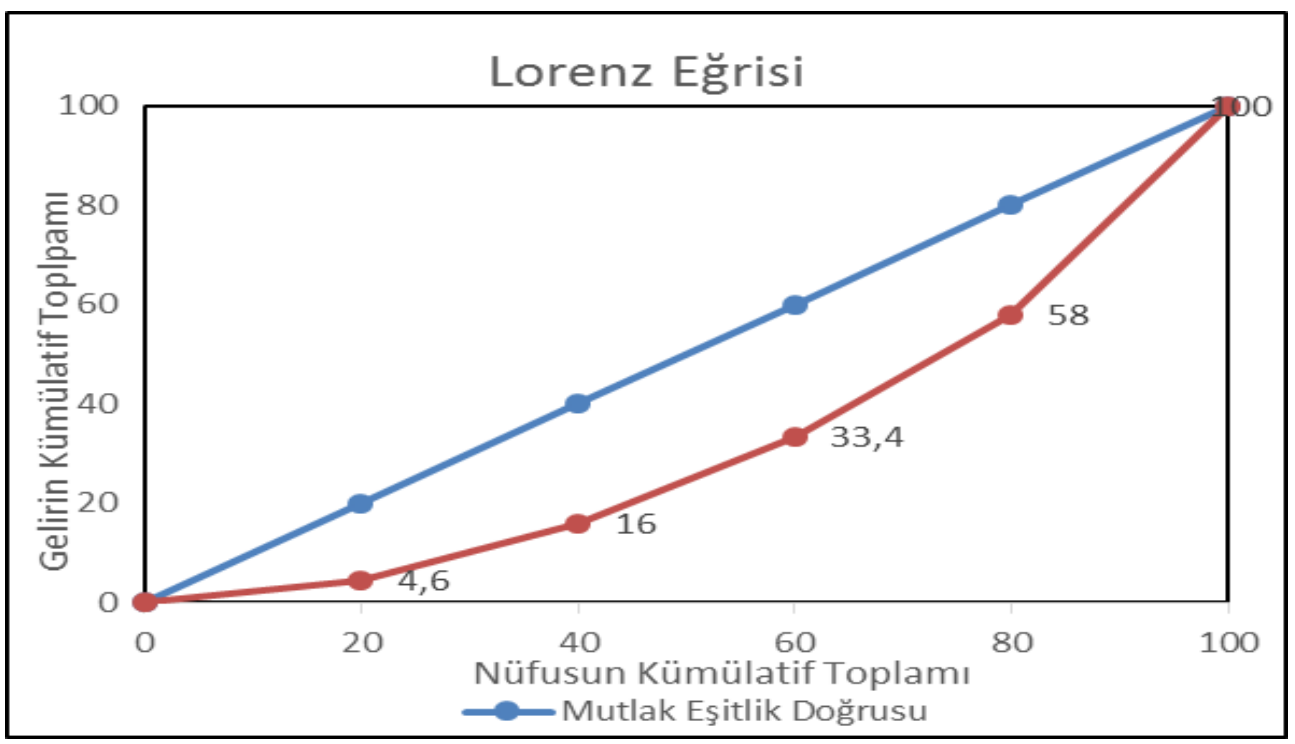

Kaynak: Sorgun Temettüat Defterleri, 1844-1845.

Sorgun Kazasında gelir dağılımı eşitsizliği Gini katsayısı ile tespit edilmiştir. Bu bağlamda 1844-1845 yılları için Sorgun Kazasında Gini katsayısı 0,3743 olarak tespit edilmiş̧ir. Diğer yandan Sorgun Kazasına ait temettüat defterlerinden elde edilen hane geliri verileri kullanılarak göreli yoksulluk oranı da hesaplanmıştır. Buna göre Sorgun Kazasında toplumun \%20'si, göreli yoksulluk sınırının altında yer almaktadır. Bir diğer deyişle hanelerin \%20'si, diğerlerine göre yoksuldur. Yoksulluk sınırı altında yaşayan hanelerin $\% 45$ 'i zirai faaliyetle uğraşırken, \%16'sı azab ve \%13'ü ise çobandır. Hanelerin \%22,4'ünün 
herhangi bir geliri bulunmamasına rağmen kendilerinden vergi tahsilatı yapıldığı tespit edilmiştir. Bunun nedeni gayrimüslim hanelerden gelirden bağımsız olarak cizye tahsilatı yapılması, diğer hanelerde ise elde edilen mahsulle birlikte hayvanların önceden belirlenen bir fiyatla değerlendirilmesi ve bunun üzerinden aşar ve diğer resimlerin alınmasıdır. Böylece vergi uygulaması sonrası söz konusu hanelerin yoksulluğu derinleşmektedir. Göreli yoksulluk sınırının altında yaşayan hanelerin yerleşim durumuna bakıldığında ise hanelerin \%14'ü Köhne-i Kebir'de ikamet etmektedir. Karamağara \%11,2 ile ikinci sırada Calatlu ise $\% 4,7$ ile üçüncü sırada yer almaktadır. En zengin beşinci dilimde yer alan hanelerin $\% 5$ 'i yine Karamağara'da yaşamaktadır. Nefs-i Sorgun'da yer alan hanelerin \%3,9'u en zengin dilimdeyken, Mihal ve Karakız'da ise bu oran \%3,4'tür.

Tablo: 5

\section{Meslek Unsurlarının \%20'lik Dilimler İtibariyle Gelirden Aldığı Pay}

\begin{tabular}{|l|c|c|c|c|c|c|}
\hline Meslek & $\mathbf{1 . \% 2 0}$ & $\mathbf{2 .} \% \mathbf{2 0}$ & $\mathbf{3 . \% 2 0}$ & $\mathbf{4 . ~ \% 2 0}$ & $\mathbf{5 . ~ \% 2 0}$ & Toplam \\
\hline Arabac1 & 2 & 0 & 0 & 0 & 0 & 2 \\
\hline Azab & 60 & 22 & 0 & 0 & 0 & 82 \\
\hline Bakkal & 0 & 1 & 0 & 0 & 2 & 3 \\
\hline Başıboş & 7 & 0 & 0 & 0 & 0 & 7 \\
\hline Bostanc1 & 2 & 0 & 0 & 0 & 0 & 2 \\
\hline Boyacı & 0 & 0 & 1 & 0 & 0 & 1 \\
\hline Demirci & 1 & 2 & 3 & 0 & 2 & 8 \\
\hline Değirmenci & 2 & 2 & 0 & 0 & 0 & 4 \\
\hline Dikici & 0 & 2 & 0 & 0 & 0 & 2 \\
\hline Hatun & 5 & 0 & 0 & 0 & 0 & 5 \\
\hline Hizmetkâr & 22 & 6 & 0 & 0 & 0 & 28 \\
\hline Kalayci & 1 & 1 & 1 & 1 & 1 & 5 \\
\hline Keşiş & 0 & 1 & 0 & 0 & 0 & 1 \\
\hline Köşker & 0 & 1 & 0 & 0 & 1 & 2 \\
\hline Köşker Çıraklığ1 & 1 & 0 & 0 & 0 & 0 & 1 \\
\hline Muhtaç & 20 & 0 & 0 & 0 & 0 & 20 \\
\hline Süvari Sipahi & 0 & 0 & 0 & 0 & 1 & 1 \\
\hline Terzi & 0 & 1 & 0 & 0 & 0 & 1 \\
\hline Tüccar & 1 & 3 & 1 & 0 & 1 & 6 \\
\hline Tımarlı Zaptiye & 0 & 0 & 0 & 0 & 1 & 1 \\
\hline Ziraat & 179 & 315 & 371 & 379 & 370 & 1.614 \\
\hline Çerçi & 1 & 0 & 0 & 0 & 0 & 1 \\
\hline Çoban & 56 & 21 & 0 & 0 & 0 & 77 \\
\hline İmam & 10 & 2 & 1 & 0 & 0 & 13 \\
\hline- & 13 & 2 & 3 & 1 & 2 & 21 \\
\hline Toplam & $\mathbf{3 8 3}$ & $\mathbf{3 8 2}$ & $\mathbf{3 8 1}$ & $\mathbf{3 8 1}$ & $\mathbf{3 8 1}$ & $\mathbf{1 . 9 0 8}$ \\
\hline
\end{tabular}

Kaynak: Sorgun Temettiä Defterleri, 1844-1845.

Elde edilen gelirin, meslek unsurlarına göre dağılımı, \%20'lik dilimler itibariyle Tablo: 5'de gösterilmektedir. Temettüat defterlerinden tespit edilen yirmi dört farklı meslek unsuru bulunmakla birlikte, hanelerin büyük bir kısmı ziraatla uğraşmaktadır. Zirai 
faaliyetle uğraşan toplam 1.614 hanenin yaklaşık olarak \%70'inin orta ve üzeri gelir dilimlerinde yer aldığı görülmektedir. Zirai faaliyeti ise azab, çoban ve hizmetkârlar takip etmektedir. Buna göre azab, çoban ve hizmetkârların tamamı orta ve altı gelir dilimlerinde yer almaktadır. Boyacı, keşiş, köşker çıraklığı, süvari sipahi, terzi, tımarlı zaptiye ve çerçi ise birer haneden oluşmaktadır. Süvari Sipahi ile tımarlı zaptiyenin en zengin beşinci dilimde yer aldığı tespit edilmiştir. Bakkallık yapan üç hanenin ikisi en zengin dilimde yer alırken, bakkalların tamamı gayrimüslimdir. Diğer yandan yedi hane başıboş, beş hane hatun, yirmi hane de muhtaç olarak kaydedilmiş ve en yoksul birinci dilimde yer almıştır. Arabacı ve bostancı iki hane, köşker çırağı ve çerçi bir hanenin de benzer biçimde en yoksul birinci dilimde yer aldığ 1 belirlenmiştir. İmamlık yapan on üç hane reisinin onu en yoksul birinci dilimde olmak üzere tamamı, orta ve altı gelir dilimlerinde yer almaktadır.

Sorgun Kazasında üretilen değerin mesleklere göre dağılımında ise çiftçi kesiminin ağırlıkta olduğu görülmektedir. Elde edilen toplam gelirin \%94’ü ziraatla uğraşan hanelerce alınmaktadır. Diğer meslek unsurlarından hizmetkârlar, toplam gelirin yalnızca $\%$ 0,4'ünü alırken azablar \%1,5'ini, çobanlar ise \%1,3'ünü almaktadır. Gelir dağılımında en zengin beşinci \%20'lik dilimde yer alan tımarlı zaptiyenin yıllık geliri 1.043 kuruştur. Benzer biçimde yine en zengin dilimde yer alan hanelerden süvari sipahinin geliri ise yıllık 1.800 kuruş olarak tespit edilmiştir. Gayrimüslim mahallesinde ikamet eden iki köşkerden en zengin dilimde yer alanın yıllık geliri 1.260 kuruş, en yoksul ikinci \%20'lik dilimde yer alan diğer köşkerin yıllık geliri ise 243 kuruştur. Benzer biçimde gayrimüslim olarak Köhnei Kebir'de ikamet eden bakkalların ikisi en zengin beşinci dilimde yer alırken yıllık toplam kazançları 1.058 ve 1.582 kuruştur. En yoksul ikinci dilimde yer alan üçüncü bakkalda ise bu tutar 318 kuruş olarak bulunmuştur. Muhtaç, hatun, başıboş ya da amel-mande olarak sınıflandırılan hanelerin geliri sıfır ile kırk kuruş arasında değişirken, Köhne-i Kebir'de müslüman mahallesinde ikamet eden yirmi dokuz hane numaralı İmam oğlu Mehmed, başıboş olarak kaydedilmiş ve elde ettiği toplam yıllık geliri 153 kuruş olarak bulunmuştur. Gelirin niteliğine bakıldığında ise sahip olunan bostan ve hayvanların, belirlenen fiyatlar üzerinden değerlendirilmesiyle bu sonuca ulaşıldığı görülmektedir. Sorgun Kazasındaki tek terzi olan hanenin yıllık kazancı ise 263 kuruş olup, en yoksul ikinci dilimde yer almaktadır. Diğer yandan Sorgun Kazasındaki en fazla geliri elde eden kişi, Karamağara'da ikamet eden yirmi hane numaralı Emrah oğlu Musa'dır. Zirai faaliyetle uğraşan söz konusu hanenin yıllık kazancı ise 3.346,75 kuruştur.

Tanzimatla birlikte aşar ve ağnam dışındaki örfi vergilerin kaldırılarak "vergi-i mahsusa" ismiyle uygulamaya konulan vergi, ödeme gücünü referans almakta ve haneler arasında dağıtılmaktadır. Bu bağlamda Sorgun Kazasında hanelerden toplanan vergi-i mahsusa 198.525,25 kuruştur. Toplanan verginin yaklaşık olarak \%94'ü (186.113,25 kuruş), çiftçiler tarafından ödenirken, azablar \%1,4'ünü, çobanlar \%1,5'ini ve hizmetkârlar ise \%,4'ünü ödemişlerdir. Diğer yandan söz konusu verginin bazı muhtaçlardan dahi çeşitli miktarlarda alındığg görülmektedir. Örneğin Eynelli-yi Kebir'de ikamet eden dokuz hane numaralı Yazıcı oğlu Osman'ın ödediği vergi-i mahsusa 48 kuruşken, Darıcı'da ikamet eden 
Arzaman oğlu Memiş’in ödediği vergi-i mahsusa ise 5 kuruştur. Sorgun Kazasında ödenen ortalama vergi-i mahsusa 104 kuruş olup, toplam gelire oranı \%18,3 olarak tespit edilmiştir. $\mathrm{Bu}$ oran aynı zamanda vergi yükünü göstermektedir. Aşar ve rüsumat adı altında buğday, arpa, burçak, bahçe, bostan ve kovan üzerinden alınan zirai verginin toplamı ise 105.662,28 kuruştur. Ortalama ödenen aşar ve rüsumat ise 56 kuruştur. Vergi-i mahsusa ile birlikte aşar ve rüsumatın, gelire oranlanması sonucu toplam vergi yüküne ulaşılmaktadır. Buna göre Sorgun Kazası'nın vergi yükü \%29,2 olarak hesaplanmıştır. Temettüat tahrirleri çerçevesinde ortalama vergi yükü Vidin Sancağı'nda \%12,08, Varna Sancağı'nda \%4,27, Bilecik Sancağı'nda \%11,29, Kastamonu Sancağı'nda \%35,55, Kocaeli Sancağı'nda $\% 16,49$, Bozok Sancağı'nda \%18,11, Denizli Sancağı'nda \%13,10, Ankara Eyaleti'nde \%21 ve Ödemiş Kasabası'nda \%25'dir (Karakaş, 1995: 59; Şenel, 2002: 215; Güran, 1984: 317). Diğer yandan vergi yükünün farklı haneler için de değiştiği belirlenmiştir. Örneğin Köhne-i Kebir'de demircilik yapan gayrimüslim hanenin vergi yükü \%1,2'dir. En zengin beşinci \%20'lik dilimde yer alan ve tımarlı zaptiye olan hane için vergi yükü ise \% $\%, 5$ olarak hesaplanmıştır. Benzer biçimde yine en zengin dilimde yer alan ve bakkal olan hanede gerçekleşen vergi yükü ise \%10,4'tür. Sorgun Kazasında gelir dilimlerine göre vergi yükü Tablo: 6'da gösterilmektedir.

Tablo: 6

\section{Sorgun Kazasında Gelir Dilimleri İtibariyle Vergi Yükü}

\begin{tabular}{|l|c|}
\hline Gelir Dilimleri & Vergi Yükü \\
\hline Birinci \%20'lik Dilim & $\% 39$ \\
\hline İkinci \%20'lik Dilim & $\% 26,6$ \\
\hline Üçüncü \%20'lik Dilim & $\% 28$ \\
\hline Dördüncü \%20'lik Dilim & $\% 27$ \\
\hline Beşinci \%20'lik Dilim & $\% 27$ \\
\hline Toplam Vergi Yükü & $\% 29,2$ \\
\hline
\end{tabular}

Kaynak: Sorgun Temettüat Defterleri, 1844-1845.

Tablo: 6'da görüldüğü üzere, ortalama vergi oranı en yoksul birinci \%20'lik dilimde \%39 iken, en zengin beşinci \%20'lik dilimde ise \%27'dir. Dolayısıyla yoksul kesimin katlandığı vergi yükü, zengin kesime göre daha fazladır. Vergi uygulamasının gelir dağılımı üzerindeki etkisi, Gini Katsayısı ile ölçüldüğünde, vergi sonrası Gini Katsayısı 0,4031 olarak hesaplanmıştır. Bununla birlikte vergi sonrası göreli yoksulluk oranı ise \%31'dir. Sonuç olarak bu durum, vergi sonrası gelir dağılımını olumsuz yönde etkilemektedir. Vergi sonrası gelirin \%20'lik dilimler itibariyle dağılımı Tablo: 7'de gösterilmektedir. Buna göre vergi sonrası toplam gelirden alınan pay, vergi öncesi duruma göre en yoksul birinci dilimde azalırken, en zengin beşinci dilimde artmıştır. Vergi uygulamasının gelir dağılımı üzerindeki olumsuz etkisi ise aşar ve rüsumatın gelirden bağımsız olarak hesaplanmasının yanı sıra, vergi-i mahsusa uygulamasının hanelerin ödeme gücünü tam olarak yansıtmamasından kaynaklanmaktadır. Örneğin Duralidayılı'da ikamet eden ve en zengin beşinci dilimde yer alan yirmi bir hane numaralı Çiftçi Kara Kasım oğlu 
Mahmud, vergi-i mahsusa ödemezken, Karamağara'da ikamet eden ve en yoksul birinci dilimde yer alan yetmiş altı hane numaralı Çiftçi Ahmed Ağa oğlu Topal Mehmed Ağa, ödediği 420,5 kuruşluk vergi-i mahsusa ile bu vergiyi en fazla ödeyen sekizinci kişidir.

Tablo: 7

Sorgun Kazasında Nüfusun \%20'lik Dilimler İtibariyle Vergi Sonrası Gelirden Aldığı Pay

\begin{tabular}{|l|c|c|}
\hline Gelir Dilimleri & Gelirden Alınan Pay (\%) & Kümülatif Toplam (\%) \\
\hline Birinci \%20'lik Dilim & 3 & 3 \\
\hline İkinci \%20'lik Dilim & 11,4 & 14,4 \\
\hline Üçüncü \%20'lik Dilim & 17,5 & 31,9 \\
\hline Dördüncü \%20'lik Dilim & 25 & 56,9 \\
\hline Beşinci \%20'lik Dilim & 43,1 & 100 \\
\hline
\end{tabular}

Kaynak: Sorgun Temettüat Defterleri, 1844-1845.

\section{Sonuç}

XIX. yüzyıl ortalarında Tanzimat Fermanı'yla birlikte değişen vergi sistemi çerçevesinde uygulamaya konulan temettüat tahrirleri, Osmanlı İmparatorluğu'nda sosyoekonomik yapıya ilişkin ayrıntılı bilgiler vermektedir. Çalışmada, Sivas Eyaleti, Bozok Sancağına bağlı Sorgun Kazası 1844-1845 temettüat tahrirleri verilerine dayanılarak Sorgun'da haneler arası gelir dağılımıyla birlikte göreli yoksulluk oranı analiz edilmiştir. Gelir eşitsizliğinin Gini Katsayısıyla ölçüldüğü çalışmada, vergi uygulamasının gelir dağılımı üzerindeki etkisi de ayrıca incelenmiştir. Toplam gelirin, nüfusun yüzdelik dilimleri itibariyle dağılımı ise Lorenz Eğrisi yardımıyla gösterilmiştir.

Çalışmadan elde edilen sonuçlara göre en yoksul birinci \%20'lik dilimde yer alan haneler, toplam gelirin \%4,6'sını alırken, en zengin \%20'lik dilimde yer alan haneler de bu oran \%42'dir. Vergi uygulaması sonrası söz konusu oranlar ise sirasıyla \%3 ve \%43,1'dir. En yoksul dilimde yıllık ortalama gelir 130 kuruş, en zengin dilimde ise 700 kuruştur. Toplam gelirin mesleklere göre dağılımında ise çiftçi kesiminin ağırlıkta olduğu belirlenmiştir. Toplam gelirin \%94’ü çiftçi kesimi tarafından elde edilmektedir. Diğer meslek unsurlarından hizmetkârlar, toplam gelirin yalnızca \%0,4'ünü alırken azablar $\% 1,5$ 'ini, çobanlar ise \%1,3'ünü almaktadır. Sorgun Kazasında 1844-1845 yılları için Gini Katsayıs1, vergi tahsilatından önce 0,3743 , vergi tahsilatından sonra ise 0,4031 olarak hesaplanmıştır. $\mathrm{Bu}$ bağlamda ödeme gücünü referans alan Tanzimat dönemi vergi reformlarının, Sorgun özelinde gelir dağılımını olumsuz yönde etkilediği belirlenmiştir. Bu durum özellikle vergi-i mahsusanın hane gelirlerini referans almaması ve gelir düzeylerine göre farklılık göstermesinden kaynaklanmaktadır. Hanelerin \%22,4'ünün herhangi bir geliri bulunmamasına rağmen kendilerinden vergi tahsilatı yapılması bu bulguyu desteklemektedir. Nitekim en yoksul birinci dilimde yer alan hanelerde vergi yükü \%39, en zengin dilimde yer alan hanelerde ise \%27'dir. Bununla birlikte Sorgun Kazasında 
hesaplanan göreli yoksulluk oranı ise vergi tahsilatından önce $\% 20$, vergi tahsilatından sonra $\% 31$ 'dir. Yoksulluk sınırı altında yaşayan hanelerin $\% 45$ 'i zirai faaliyetle uğraşırken, $\% 16$ 's1 azab ve \%13'ü ise çobandır.

\section{Kaynakça}

Abadan, Y. (2012), “Tanzimat Fermanı'nın Tahlili”, H. İnalcık, \& M. Seyitdanlığlu (Dü) içinde: Tanzimat, Değişim Sürecinde Osmanlı İmparatorluğu, İstanbul: Türkiye İş Bankası Kültür Yayınları, 57-88.

Adıyeke, N. (2000), "Temettuat Sayımları ve Bu Sayımları Düzenleyen Nizamname Örnekleri”, OTAM (Ankara Üniversitesi Osmanlı Tarihi Araştırma ve Uygulama Merkezi Dergisi) (11), 769-823.

Akgündüz, A. \& S. Öztürk (2000), Yozgat Temettüat Defterleri, I-II-III. İstanbul: Yimpaş.

Akşin, S. (1994), "Sened-i İttifak ile Magna Carta'nın Karşılaştırılması", Ankara Üniversitesi Dil ve

Tarih-Coğrafya Fakültesi Tarih Bölümü Tarih Araştırmaları Dergisi, 16(27), 115-123.

Aliye, F. (1995), Ahmet Cevdet Paşa ve Zamanı, İstanbul: Bedir Yayınevi.

Barkan, Ö. (1960), “H. 974-975 (M. 1567-1568) Mali Y1lına Âit Bir Osmanlı Bütçesi”, İktisat Fakültesi Mecmuasl, XIX(1-4), 277-332.

Bozkurt, N. (2011), "1844-1845 Tarihli Temettüat Defterine Göre Kütahya Sancağı Dazkırı Kazası Evciler Köyü'nün Sosyal ve Ekonomik Yapısı”, Uluslararası Sosyal Araştırmalar Dergisi, 4(19), 138-156.

Cankabal, H. \& A. Filiztekin (2013), Wealth and Inequality in Ottoman Lands in the Early Modern Period, AALIMS: 〈http://aalims.org/uploads/Rice_v1.pdf>, 12.04.2014.

Cengiz, A. (2010), "Temettüat Defterine Göre XIX. Yüzyllın Ortalarında Pursaklar'da SosyoEkonomik Yapı", Tarihin Peşinde, (4), 1-24.

Cezar, Y. (1985), “Tanzimat'a Doğru Osmanlı Maliyesi”, A. Gündüz (Dü.) içinde, Tanzimat'tan Cumhuriyet'e Türkiye Ansiklopedisi, İstanbul: İletişim Yayınları, 924-933.

Coşgel, M. \& B. Ergene (2012), "Inequality of Wealth in the Ottoman Empire: War, Weather, and Long-Term Trends in Eighteenth-Century Kastamonu", The Journal of Economic History, 72(2), 308-331.

Danışman, Z. (1985), Koçi Bey Risalesi, Ankara: Kültür ve Turizm Bakanlığı Yayınları.

Değerli, A. (2013), “Temettuat Defterine Göre Seydişehir'in Sosyoekonomik Yapısı”, Süleyman Demirel Üniversitesi Fen Edebiyat Fakültesi Sosyal Bilimler Dergisi, (30), 89-110.

Efe, A. (2006), "1260-61 / 1844-45 Temettuat Sayımı Işı̆̆ında Çukurhisar Köyünün Ekonomik ve Sosyal Görüntüsü”, Sosyal Bilimler Dergisi, 1, 19-51.

Ergene, B. \& A. Berker (2008), "Wealth and Inequality in 18th Century Kastamonu: Estimations for the Muslim Majority", International Journal of Middle East Studies, 40(1), 23-46.

Ergene, B. \& A. Kaygun \& M. Coşgel (2013), "A temporal analysis of wealth in Eighteenth Century Ottoman Kastamonu", Continuity and Change, 28(1), May, 1-26.

Foster, J. (1998), “Absolute versus Relative Poverty", The American Economic Review, 88(2), 335341. 
Geçer, A. (2012), "Temettüat Defterine Göre Mut'un Sosyo-Eknomik ve Demografik Yapısı (18441845)", Turkish Studies, 7(4), 1749-1777.

Genç, M. \& E. Özvar (2007), Osmanlı Maliyesi: Kurumlar ve Bütçeler. İstanbul: Osmanlı Bankası Arşiv ve Araştırma Merkezi Yayınları.

Gökmen, E. (2008), “Saruhan Sancağında Temettuat Tahriri”, Bilig, (45), 73-90.

Güran, T. (1985), “Ondokuzuncu Yüzyıl Ortalarında Ödemiş Kasabasının Sosyo-Ekonomik Özellikleri”, İktisat Fakültesi Mecmuast, 41(1-4), 301-319.

Güran, T. (1987), “Osmanlı Tarım Ekonomisi, 1840-1910”, Türk İktisat Tarihi Yıllı̆̆g, (1), 225-303. Güran, T. (2000), “19. Yüzy1l Temettüat Tahrirleri”, H. İnalcık, \& Ş. Pamuk (Dü) içinde: Osmanlı Devleti'nde Bilgi ve İstatistik, Ankara: T.C. Başbakanlık Devlet İstatistik Enstitüsü, 7394.

Güran, T. (2011), “Tanzimat Dönemi Osmanlı Maliyesi”, Iktisat Fakültesi Mecmuası, 49, 79-95.

İnalcık, H. (1964), “Sened-i İttifak ve Gülhane Hatt-1 Hümayunu”, Belleten, XVIII(112), 603-622.

İnalcık, H. (2012),” Tanzimat Nedir?”, H. İnalcık, \& M. Seyitdanlığlu (Dü) içinde: Tanzimat, Değişim Sürecinde Osmanlı İmparatorluğu, İstanbul: Türkiye İş Bankası Kültür Yayınlar1, 29-56.

İnalcık, H. (2012), “Tanzimat'ın Uygulanması ve Sosyal Tepkiler”, H. İnalcık, \& M. Seyitdanlığlu (Dü) içinde: Tanzimat, Değişim Sürecinde Osmanlı İmparatorluğu, İstanbul: Türkiye İş Bankası Kültür Yayınları, 169-195.

İnalcık, H. (2013), Devlet-i 'Aliyye Osmanlı İmparatorluğu Üzerine Araştırmalar-I, Klasik Dönem (1302-1606) Siyasal, Kurumsal ve Ekonomik Gelişim (Elli İkinci b.), (E. Yalçın, Dü.) İstanbul: Türkiye İş Bankası Kültür Yayınları.

İnalcık, H. (2014), Devlet-i 'Aliyye Osmanlı İmparatorluğu Üzerine Araştırmalar-II, Tagayyür ve Fesad (1603-1656): Bozuluş ve Kargaşa Dönemi, (E. Yalçın, Dü.) İstanbul: Türkiye İş Bankası Kültür Yayınları.

Karakaş, M. (1995), "Maliye Nezareti Temettüat Defterlerine Göre 1844 Yılında Bolu Kazasının Sosyal ve Ekonomik Durumu”, Yayınlanmamış Yüksek Lisans Tezi, İstanbul Üniversitesi, Sosyal Bilimler Enstitüsü, İstanbul 1995.

Karal, E.Z. (1995), Osmanlı İmparatorluğunda İlk Nüfus Sayımı 1831, Ankara: T.C. Başbakanlık Devlet İstatistik Enstitüsü.

Karal, E.Z. (2011), Osmanlı Tarihi, Nizam-ı Cedid ve Tanzimat Devirleri (1789-1856) (Dokuzuncu b.), Ankara: Türk Tarih Kurumu.

Kaynar, R. (1991), Mustafa Reşit Paşa ve Tanzimat, Ankara: Türk Tarih Kurumu.

Kütükoğlu, M. (1999), “İzmir Temettü Sayımları ve Yabancı Tebaa”, Belleten, 63(238), 755-774.

Kütükoğlu, M.S. (1995), “Osmanlı Sosyal ve İktisadi Tarihi Kaynaklarından Temettü Defterleri”, Belleten, LIX(225), 395-418.

Lindert, P. (2000), "When Did Inequality Rise in Britain and America?", Journal of Income Distribution, 9, 11-25.

Lindert, P. \& J. Williamson (2012)," American Incomes, 1774 - 1860”, NBER Working Paper No. 18396, <http://www.nber.org/papers/w18396>, 25.02.2014.

Lütfi, P. (1991), Âsafnâme, (M. Kütükoğlu, Dü.) İstanbul: İstanbul Üniversitesi Edebiyat Fakültesi Tarih Araştırma Merkezi. 
Morrisson, C. \& W. Snyder (2000), "The Income Inequality of France in Historical Perspective", European Review of Economic History, 4, 59-83.

Muşmal, H. (2008), “XIX. Yüzyılın Ortalarında Çumra'nın Sosyo-Ekonomik Görüntüsü (10353 Numaralı Temettüat Defteri Göre)”, Türkiyat Araştırmaları Dergisi, (24), 254-275.

Öztürk, G. \& Ş. Atam (2011), “Temettuat Defterlerine Göre 19. Yüzyılın Ortalarında Priştine”, TÜBAR, (30), 283-310.

Öztürk, S. (1995), “XIX. Yüzyılda Söğüd'ün Sosyo-Ekonomik Yapısı”, Türk Dünyası Tarih Dergisi, (106),

Öztürk, S. (1996), Tanzimat Döneminde Bir Anadolu Şehri Bilecik, İstanbul: Kitabevi Yayınları.

Pamuk, Ş. (2012), Osmanlıdan Cumhuriyete Küreselleşme, Iktisat Politikaları ve Büyüme (Üçüncü b.), (A. Berktay, Dü.) İstanbul: Türkiye İş Bankası Kültür Yayınları.

Pamuk, Ş. (2013), Osmanlı Ekonomisi ve Kurumları (Dördüncü b.), (A. Berktay, Dü.) İstanbul: Türkiye İş Bankası Kültür Yayınları.

Polat, S. (2010), Sorgun Temettüat Defterleri, Sorgun Belediyesi: <http://www.sorgun.bel.tr/>, 22.12.2013.

Polat, S. (2010), “Temettüat Defterlerine Göre Sorgun Kazasının Sosyo-Ekonomik Yapısı”, Yayınlanmamış Yükseklisans Tezi, Bozok Üniversitesi, Sosyal Bilimler Enstitüsü, Yozgat.

Pradhan, M. \& M. Ravallion (2011), Measuring Poverty Using Qualitative Perceptions of Welfare, Washington: The World Bank.

Ravallion, M. (1998), "Poverty Lines in Theory and Practice", LSMS Working Paper Number: 133. Washington, D.C.: The World Bank.

Sayın, A.V. (1999), Tekâlif Kavaidi (Osmanlı Vergi Sistemi), (F. Özkan, Çev.) Ankara: T.C. Maliye Bakanlığı.

Shaw, S.J. (1985), “Tanzimat'tan Sonra Osmanlı Vergi Sistemi”, Tanzimat'tan Cumhuriyet'e Türkiye Ansiklopedisi, A. Gündüz, Çev., Cilt Dört, içinde: İstanbul: İletişim Yayınları, 934-946.

Shaw, S.J. \& E.K. Shaw (1983), Osmanlı Imparatorluğu ve Modern Türkiye, İstanbul: E Yayınları.

Soltow, L. (1983), "Wealth at the End of the Eighteenth Century", The Journal of Economic History, 43(3), 617-633.

Şenel, Ş. (2002), "XIX. Yüzyıl Ortalarında Ankara Eyalet Merkezi'nin Sosyal ve İktisadi Durumu

(H.1260-1261/M.1844-1845 Tarihli Temettüat Defterlerine Göre)", Yayınlanmamış

Doktora Tezi, Gazi Üniversitesi, Sosyal Bilimler Enstitüsü, Ankara.

Şener, A. (2007), Sona Doğru Osmanlı (İkinci b.), Ankara: Birleşik Yayınevi.

Şener, S. (2008), “19. Yüzyılda Osmanlı Kırsalında Ekonomik ve Sosyal Yapı”, İktisat Işsletme ve Finans, 23(262), 112-141.

T.C. Başbakanlık (2010), Başbakanlık Osmanlı Arşivi Rehberi, Yayın No: 108. T.C. Başbakanlık Devlet Arşivleri Genel Müdürlüğü.

Taşkaya, A. (2013), "1844 Tarihli Temettüat Kayıtlarına Göre Kütahya Sancağına Bağlı Şaphane Köyünün Sosyal Ekonomik Yapısı”, Dumlupınar Üniversitesi Sosyal Bilimler Dergisi, (35), 235-252. 
Tekin, S. (2012), “Temettüat Defterlerine Göre Turgutlu'nun Sosyal ve Ekonomik Durumu (18441845)", Tarih Okulu, (XII), 193-220.

Türkiye İstatistik Kurumu TÜİK (2011), Yoksulluk Çalışması, <http://www.tuik.gov.tr/PreHaberBultenleri.do?id=10952>, 11.06.2012.

Brown, M.C. (1994), "Using Gini-Style Indices to Evaluate the Spatial Patterns of Health Practitioners: Theoretical Considerations and an Application Based on Alberta Data", Social Science \& Medicine, 38(9), 1243-1256.

Uzunçarşıl1, İ.H. (2011), Osmanlı Tarihi (Yedi b., Cilt Üç), Ankara: Türk Tarih Kurumu.

Velidedeoğlu, H. (1989), 1789 Devrimi İlkelerinin Osmanlı'daki Yansımaları, Cumhuriyet.

Yalçın, A. (2004), "Temettüat Defterlerine Göre 19. Yüzyıl Ortalarında Silifke Kazasının Sosyal ve Ekonomik Yapısı”, OTAM (Ankara Üniversitesi Osmanlı Tarihi Araştırma ve Uygulama Merkezi Dergisi), (15), 13-87.

Zaidi, M.A. (1992), "Relative Poverty in Pakistan An Estimation from the Household Income and Expenditure Survey (1984-85)", The Pakistan Development Review, 31(4), 955-974. 
Sorgun Kazası XIX. Yüzyı1 Temettüat Defterleri Üzerinden Gelir Dağılımı ve Göreli Yoksulluk Üzerine Bir İnceleme

Ek: 1

Sivas Eyaleti, Bozok Sancağı, Sorgun Kazasına Bağlı Köylerin \%20'lik Dilimler İtibariyle Gelirden Aldığı Pay

\begin{tabular}{|c|c|c|c|c|c|c|}
\hline Köy & $1 . \% 20$ & $2 . \% 20$ & $3 . \% 20$ & $4 . \% 20$ & $5 . \% 20$ & Toplam \\
\hline Abdurrahmanbeyli & 0 & 1 & 0 & 3 & 2 & 6 \\
\hline Ahmedfakihli & 0 & 4 & 6 & 9 & 6 & 25 \\
\hline Aktaş & 0 & 5 & 0 & 3 & 4 & 12 \\
\hline Alibartekyesi & 2 & 4 & 11 & 2 & 0 & 19 \\
\hline Arabli & 9 & 6 & 10 & 17 & 1 & 43 \\
\hline Ayrıdam & 0 & 5 & 7 & 3 & 2 & 17 \\
\hline Ayvalı & 1 & 2 & 0 & 1 & 0 & 4 \\
\hline Azab & 2 & 0 & 0 & 0 & 0 & 2 \\
\hline Ağcin & 0 & 3 & 0 & 4 & 6 & 13 \\
\hline Babalı & 7 & 5 & 2 & 3 & 8 & 25 \\
\hline Balc1 & 2 & 4 & 7 & 9 & 2 & 24 \\
\hline Baltasarıları & 9 & 4 & 2 & 3 & 3 & 21 \\
\hline Başıüyük & 2 & 6 & 9 & 6 & 7 & 30 \\
\hline Belekili & 0 & 15 & 2 & 7 & 3 & 27 \\
\hline Belencumafakihli & 1 & 3 & 1 & 7 & 8 & 20 \\
\hline Belpınar & 0 & 0 & 6 & 0 & 1 & 7 \\
\hline Beyyurdu & 1 & 7 & 0 & 4 & 6 & 18 \\
\hline Boğazcumafakihli & 0 & 0 & 2 & 0 & 3 & 5 \\
\hline Burunviran & 1 & 1 & 6 & 9 & 2 & 19 \\
\hline Buzacioğlu & 1 & 4 & 2 & 1 & 1 & 9 \\
\hline Calatlı & 18 & 7 & 4 & 4 & 5 & 38 \\
\hline Cihanpaşa & 1 & 11 & 8 & 3 & 0 & 23 \\
\hline Cihanşarlu & 10 & 11 & 5 & 6 & 2 & 34 \\
\hline Cumafakihli-yi zir & 11 & 12 & 10 & 9 & 8 & 50 \\
\hline Darıc1 & 9 & 12 & 8 & 6 & 15 & 50 \\
\hline Dağyenicesi & 1 & 2 & 1 & 1 & 8 & 13 \\
\hline Deremüminli & 4 & 8 & 3 & 3 & 2 & 20 \\
\hline Dişli & 4 & 6 & 7 & 13 & 7 & 37 \\
\hline Duralidayılı & 2 & 7 & 8 & 4 & 1 & 22 \\
\hline Erkekli & 2 & 2 & 2 & 3 & 7 & 16 \\
\hline Eynelli-yi Kebir & 6 & 7 & 3 & 5 & 3 & 24 \\
\hline Eynelli-yi Sağir & 4 & 5 & 5 & 1 & 3 & 18 \\
\hline Fakihbeyli & 7 & 11 & 7 & 1 & 4 & 30 \\
\hline Faraşlı & 5 & 2 & 9 & 2 & 0 & 18 \\
\hline Gamberli & 3 & 2 & 3 & 3 & 0 & 11 \\
\hline Gevrek & 5 & 1 & 14 & 8 & 7 & 35 \\
\hline Güllük & 1 & 11 & 3 & 2 & 11 & 28 \\
\hline Hacıbeğli & 1 & 2 & 2 & 3 & 5 & 13 \\
\hline Halilfakihli & 2 & 4 & 6 & 1 & 6 & 19 \\
\hline Hoşumlu & 3 & 5 & 9 & 7 & 4 & 28 \\
\hline Kafirviran & 1 & 0 & 4 & 5 & 3 & 13 \\
\hline Karabel & 0 & 0 & 1 & 0 & 11 & 12 \\
\hline Karahacıl1-y1 Kebir & 3 & 4 & 3 & 1 & 3 & 14 \\
\hline Karakaya & 3 & 2 & 0 & 1 & 3 & 9 \\
\hline Karakız & 10 & 3 & 9 & 12 & 13 & 47 \\
\hline
\end{tabular}


Ahmet Burçin YERELİ \& Altuğ Murat KÖKTAŞ \& Işı1 Şirin SELÇUK

\begin{tabular}{|c|c|c|c|c|c|c|}
\hline Karamağara & 43 & 3 & 8 & 7 & 19 & 80 \\
\hline Karapınar & 3 & 2 & 5 & 7 & 2 & 19 \\
\hline Karatepe & 1 & 9 & 1 & 6 & 0 & 17 \\
\hline Karaveli & 6 & 1 & 4 & 3 & 4 & 18 \\
\hline Kavakalanı & 3 & 3 & 1 & 2 & 3 & 12 \\
\hline Kavurgalı & 5 & 4 & 6 & 2 & 2 & 19 \\
\hline Kayakışla & 2 & 6 & 5 & 7 & 6 & 26 \\
\hline Kemhallu & 5 & 3 & 4 & 1 & 2 & 15 \\
\hline Kuzgun & 0 & 4 & 0 & 0 & 0 & 4 \\
\hline Köhne-i Kebir & 53 & 20 & 15 & 9 & 20 & 117 \\
\hline Körpınar & 0 & 0 & 0 & 0 & 2 & 2 \\
\hline Kötüköy & 2 & 5 & 4 & 2 & 6 & 19 \\
\hline Köçekkömü & 2 & 5 & 3 & 0 & 0 & 10 \\
\hline Külhöyük & 13 & 7 & 10 & 2 & 2 & 34 \\
\hline Kürdköyü & 1 & 0 & 2 & 1 & 6 & 10 \\
\hline Kırım & 0 & 1 & 5 & 6 & 3 & 15 \\
\hline Kiziltepe & 7 & 9 & 13 & 11 & 0 & 40 \\
\hline Manşar & 10 & 7 & 5 & 8 & 4 & 34 \\
\hline Mihal & 3 & 2 & 7 & 2 & 13 & 27 \\
\hline Mirahurlu & 3 & 4 & 3 & 10 & 6 & 26 \\
\hline Nefs-i Sorgun & 7 & 12 & 16 & 23 & 15 & 73 \\
\hline Ocaklı & 4 & 2 & 0 & 3 & 7 & 16 \\
\hline Recebli & 6 & 5 & 0 & 3 & 1 & 15 \\
\hline Sarıhacılı & 3 & 2 & 0 & 0 & 1 & 6 \\
\hline Taşlıgeçit & 2 & 0 & 1 & 5 & 0 & 8 \\
\hline Tiftik & 0 & 1 & 2 & 7 & 1 & 11 \\
\hline Tulum & 2 & 0 & 6 & 12 & 16 & 36 \\
\hline Yaycilar & 0 & 0 & 11 & 9 & 6 & 26 \\
\hline Yazılıtaş & 5 & 2 & 7 & 4 & 8 & 26 \\
\hline Yeniceköy & 1 & 2 & 5 & 1 & 6 & 15 \\
\hline Yerçeçayır & 10 & 4 & 2 & 3 & 3 & 22 \\
\hline Yünalanı & 0 & 0 & 0 & 2 & 0 & 2 \\
\hline Çavuşlu & 0 & 3 & 2 & 0 & 0 & 5 \\
\hline Çeltek & 11 & 0 & 0 & 0 & 2 & 13 \\
\hline Çoban & 1 & 0 & 0 & 0 & 0 & 1 \\
\hline Çötelli & 5 & 6 & 5 & 9 & 4 & 29 \\
\hline Öyük & 1 & 7 & 2 & 3 & 1 & 14 \\
\hline İkikara & 2 & 6 & 4 & 1 & 5 & 18 \\
\hline İncesu & 0 & 5 & 5 & 0 & 0 & 10 \\
\hline İplikli & 1 & 2 & 0 & 1 & 0 & 4 \\
\hline İsmailhacılı & 0 & 2 & 3 & 5 & 3 & 13 \\
\hline İzibüyük & 1 & 3 & 2 & 5 & 0 & 11 \\
\hline Şahmuradl1 & 5 & 6 & 0 & 4 & 6 & 21 \\
\hline- & 0 & 1 & 0 & 0 & 0 & 1 \\
\hline Toplam & 383 & 382 & 381 & 381 & 381 & 1.908 \\
\hline
\end{tabular}

Kaynak: Sorgun Temettüat Defterleri, 1844-1845. 